\title{
Artikkeli
}

\section{Talvivaara ja kommenteissa keskustelevat julkisot}

\section{Keskustelunanalyyttinen menetelmäkokeilu verkkouutisten kommentoinnista ${ }^{1}$}

\begin{abstract}
Verkkouutisten kommentoinnin tutkimus ja tätä kautta tuntemus on jäänyt mediatutkimuksen kentällä toistaiseksi vähäiseksi, ja verkkokeskusteluiden arvoa julkisen keskustelun muotona on systemaattisesti väheksytty. Tässä artikkelissa kommentointia tarkastellaan julkisen keskustelun ja ennen kaikkea julkison käsitteen viitekehyksessä. Teoreettinen ja analyyttinen perusta rakentuu ajatukselle julkiseen keskusteluun osallistuvasta julkisosta. Artikkelissani selvitän, onko kommentointi mahdollista käsittää julkisen keskustelun muodoksi ja julkisona toimimiseksi. Tähän kysymykseen kytkeytyy pyrkimys keskustelunanalyysin soveltamisesta kommentointiin: voiko kommentointia tutkia keskusteluna? Aineisto koostuu Talvivaaran kaivoksen kipsisakka-altaan vuotoa koskevasta verkkouutisoinnista ja kommentoinnista kolmessa lehdessä ja kontekstissa: paikallisessa, maakunnallisessa ja valtakunnallisessa. Menetelmällinen testaus osoittaa, että kommentointi pitää sisällään keskustelua, jossa puhutellaan sekä uutista, kommentoijia että laajempaa julkista kuulijakuntaa, "muita". Ratkaiseviksi tekijöiksi julkison kehittymisen kannalta nousevat myös muun muassa nimimerkkien vaikutus ja jaetun ongelman kontekstisidonnaisuus. Kokonaisuudessaan analyysi piirtää kuvaa varsin erilaisista julkisona keskustelemisen muodoista, joissa keskustelun laatua merkittävämmässä roolissa vaikuttavat toiminnan motiivit.
\end{abstract}

AVAINSANAT: verkkouutinen, kommentointi, julkinen keskustelu, yleisö, julkiso, ympäristöuutinen, keskustelunanalyysi

V erkkouutisten kommentoinnin tutkimus on jäänyt - ainakin suomalaisittain - varsin vähäiseksi. Vaikka tutkimuskentällä vallitsee vahva yhteisymmärrys siitä, että verkkoa ja sen käyttöä on tutkittava, uutiskommentointia ei tutkijoiden agendalla juuri näy. Verkkokeskustelujen suosio tutkimuskohteena on sen sijaan 
kasvanut jopa systemaattisesti (esim. Arpo 2005; Pietilä 2010 [2002]a; Stromer-Galley 2003; Pöyhtäri ym. 2013), ja esimerkiksi käyttäjien omaksi sisällöntuotannoksi luetaan usein osallistuminen internetin keskustelufoorumeille ja -palstoille (esim. Herkman \& Vainikka 2012a, 68, 95; Coleman \& Gøtze 2001). Asetelma on varsin ristiriitainen, sillä tutkimukset osoittavat, että kommentoinnista on muodostunut yksi yleisimmistä verkkovälitteisen osallistamisen ja osallistumisen käytännöistä (Hermida \& Thurman 2008; Domingo ym. 2008).

Vaikuttaa myös siltä, että kasvavasta tutkimuksesta huolimatta verkkokeskustelujen (ja -kommentoinnin) määrittely on jäänyt epämääräiseksi ja turhan yksiulotteiseksi. Verkkokeskustelujen kategoria saattaa pitää sisällään kaiken keskustelunomaisen toiminnan, esimerkiksi uutiskommentit, mutta samaan aikaan ymmärrys keskustelusta verkossa rajoittuu lähinnä käyttäjien toimintaan palstoilla ja foorumeissa. Käytännön teon näennäinen samankaltaisuus - puheenvuoron tai kommentin jättäminen - näyttää harhauttavan tutkijoita niiltä merkittäviltä toiminnallisilta ja toimintaympäristöön kytkeytyviltä eroilta, joita esimerkiksi uutisen kommentointiin, sosiaalisessa mediassa kommentointiin tai keskustelupalstalle kirjoittamiseen jo lähtökohtaisesti liittyy. Lisähaastetta tuo edelleen se, että kommentointi itsessään voidaan käsittää monella tapaa. Esimerkiksi Joseph M. Reagle (2015, 2-3) niputtaa verkossa kommentoinniksi liudan erilaisia toimintoja, kuten sisällöstä tykkäämisen tai sen jakamisen. Reagle kuitenkin jättää uutiskommentit lähes tyystin huomiotta kommentointi-ilmiöitä kokoavassa teoksessaan Reading the Comments (2015).

Tässä artikkelissa verkkokeskustelu toimii kattokäsitteenä varsin monimuotoiselle ja erilaisia ominaispiirteitä sisältävälle keskustelunomaiselle toiminnalle internetin luomissa julkisissa konteksteissa, kuten keskustelupalstoilla, uutissivustoilla ja sosiaalisessa mediassa. Tarkastelen uutiskommentointia yhtenä verkkokeskustelun muotona, jolla on omat erityispiirteensä ja oma toimintaympäristönsä. Jatkossa tarkoitan kommentoinnilla ja kommenteilla yksinomaan verkkouutisten kommentointia.

Verkkokeskustelujen ja kommenttien merkityksestä on esitetty ja esitetään yhä varsin eriäviä kantoja. Veikko Pietilä (2010 [2002]a, 441) totesi 2000-luvun alussa, että mediatutkimuksen kentällä "verkkovälitteisiin keskusteluihin suhtaudutaan harvoin mahdollisuuksina pohtia ratkaisuja julkisiin ongelmiin" (ks. myös Pietilä 2010 [2001]). Myös toimittajat ja esimerkiksi kunnallispoliittiset päättäjät ovat sijoittaneet verkkokeskustelut mieluusti "todellisen" julkisen keskustelun ulkopuolelle (ks. Harju 2001; Heinonen 2008; Nikunen 2011). Kritiikki juontuu usein siitä, että "julkista keskustelua on pidetty elinkelpoisen demokratian kulmakivenä" (Pietilä 2010 [2001], 373), mikä puolestaan kytkee julkisen keskustelun lähes poikkeuksetta Jürgen Habermasin (2004 [1962]) normatiivisen julkisuusteorian perintöön.

Verkkovälitteisten keskustelujen suoranaisen aliarvioinnin voi tulkita myös jonkinlaiseksi kollektiiviseksi vastareaktioksi. Kun journalismi verkossa arkipäiväistyi 2000-luvun alkupuolella, sekä mediassa että sen tutkimuksen piirissä vallitsi jonkin aikaa toiveikas odotus verkon vuoropuhelumahdollisuuksista ja demokratian uusista muodoista (ks. esim. Dahlberg 2001; Papacharissi 2002; Ridell 2006). ${ }^{2}$ Pudo- 
tus todellisuuteen on ollut jokseenkin raju, sillä odotukset eivät ole täyttyneet toivotulla tavalla: käyttäjät eivät ole tehneet internetillä ja internetissä sitä, mitä ideaaliksi muotoiltiin. Sanna Ojajärvi ja Sanna Valtonen $(2001,66)$ kuvaavat asetelmaa kahtiajakautuneeksi: vastakkain ovat pessimistinen ja optimistinen näkemys verkkokeskustelujen edesottamuksista. Itse näkisin rajanvedon myös kehityskulkuna. Yleistynyt ja yksipuolinen kritisointi edustaa käännekohtaa ajallisesti hahmottuvalla janalla, jonka alkupäähän sijoittuu odottava ja idealistinen usko verkon mahdollisuuksista.

Tämän kriittisen käännekohdan jälkeen on kuitenkin otettu ensiaskelia kohti eräänlaista sekä-että-asennetta, jonka puolesta myös Ojajärvi ja Valtonen (emt.) puhuvat (vrt. esim. Pietilä (2010 [2001]). Idealismin ja kritiikin välimaastosta etsitään realismia, mikä tarkoittaa "verkkokeskustelujen aiempaa monipuolisempaa huomioimista relevantin julkisen keskustelun areenana" (Ojajärvi \& Valtonen 2011, 67). Myös tämän tutkimuksen tavoitteena on haastaa yleistynyt kriittinen käsitys erityisesti kommentoinnin merkityksettömyydestä. Väitän, että kommentointi verkkovälitteisenä keskustelun ja kommunikoinnin muotona tarjoaa nykymuodoissaan vähintäänkin mahdollisuuksia jaettujen ongelmien ruotimiselle erilaisissa julkisissa konteksteissa.

Janne Matikaisen $(2010,3)$ mukaan "[v]erkkotutkimus lähtee usein liikkeelle pragmaattisista lähtökohdista. Halutaan tutkia jotain tiettyä verkkopalvelua, sen käyttöä, käyttäjiä, käytettävyyttä jne.”. Myös joukkoviestinnän ja journalismin tutkimuksessa verkkoa on lähestytty paljolti kulutuksen ja käytön käytäntöjen suunnasta: kuka internetiä käyttää, milloin ja kuinka paljon (esim. Herkman \& Vainikka 2012a ja 2012b). Tutkimuksessani suuntaan verkon käyttöön toisenlaisen katseen, sillä haluan selvittää, osallistuvatko verkkouutisten kommentoijat julkiseen keskusteluun ja asettuvat näin toimiessaan yleisöstä julkison positioon. Kysymyksenasettelu kytkeytyy laajaan käsitteelliseen pohdintaan, jonka ytimen muodostavat yleisö ja erityisesti julkiso. Vaikka on ilmeistä, että verkkouutisten kommentoinnissa yleisönä ja julkisona toimiminen nivoutuvat kiinnostavasti yhteen, tätä nivoutumaa ei ole toistaiseksi lähestytty kuvattujen käsitteiden kautta. Kommentointi tutkimuskohteena kaipaa myös menetelmällistä testausta, ja edellä kuvattuihin käsitteellisiin kysymyksiin kytkeytyy pyrkimys keskustelunanalyysin soveltamisesta kommenttien tutkimisessa. Keskustelunanalyyttista lähestymistapaa puoltavat sekä kysymys verkkokeskustelujen potentiaalista julkisena keskusteluna että tutkijoiden jakama ymmärrys keskustelusta julkison tärkeimpänä ominaispiirteenä. On kuitenkin ilmeistä, etteivät alun alkaen puhutun kielen analysointiin kehitetyt menetelmät sovellu ongelmitta kirjoitetun verkkosisällön tarkasteluun.

Tutkimukseni keskiössä ovat seuraavat kysymykset:

- Onko kommentointi käyttäjien (yleisön) toimintana mahdollista käsittää julkisen keskustelun muodoksi ja julkisona toimimiseksi?

- Miltä osin ja millä perustein? 
Näitä pääkysymyksiä tukevat edelleen kysymykset:

- Voidaanko kommentointia tutkia keskusteluna ja keskustelunanalyyttisin menetelmin?

- Millaisia havaintoja keskustelunanalyysi nostaa esille kommentoinnista?

- Miten erilaisten verkkolehtien kommenttiketjut ja niiden ilmentämät keskustelut eroavat toisistaan ja miksi?

En siis tarkastele yksinomaan sitä, millainen kommentoiva yleisö tai julkiso on, vaan etsin vastauksia ennen kaikkea siihen, mitä kommentointi tästä inmisryhmästä ja sen toiminnasta laajemmassa (käsitteellisessä) perspektiivissä oikeastaan kertoo. Jotta voimme tarkastella tämän ryhmän toimintaa osana julkista ja osajulkisuuksissa tapahtuvaa keskustelua, meidän on hahmotettava kommentoinnin toiminnallinen konteksti. Tässä artikkelissa tutkimuskohteena ovat yksittäisen ympäristöonnettomuuden uutisointi ja kommentointi verkkolehtien muodostamissa erilaisissa konteksteissa. Kokonaisaineisto kattaa kaivosyhtiö Talvivaaran kipsisakka-altaan vuotoon syksyllä 2012 kytkeytyvän uutisoinnin ja kommentoinnin kolmessa lehdessä: paikallisessa Sotkamo-lehdessä (jatkossa SL), maakunnallisessa Kainuun Sanomissa (jatkossa KS) ja valtakunnallisessa Helsingin Sanomissa (jatkossa HS). Lehdet tarjoavat kaksi näkökulmaa kontekstiin: Ensinnäkin kunkin lehden maantieteellinen suhde Talvivaaraan ja onnettomuuteen vaikuttaa väistämättä uutisointiin ja sen kommentointiin. Toiseksi lehdet kokonsa ja levikkinsä puolesta asettuvat varsin erilaisiin rooleihin journalistisella kentällä, jota kuvaa suomalaisittain tyypillinen kolmijako paikallinen-maakunnallinen-valtakunnallinen (esim. Hujanen 2000).

\section{Keskustelu julkison toimintana}

Artikkeli pyrkii vastaamaan kysymykseen siitä, onko kommentointi mahdollista käsittää julkison toiminnaksi osana julkista keskustelua. Näin ollen on olennaista ymmärtää, että julkiso (niin kuin yleisökin) herää eloon ainoastaan kuviteltuna käsitteenä ja käsityksenä, kielellisenä luomuksena (vrt. Coleman \& Ross 2010, 5-8; Ridell 2010; Pietilä \& Ridell 2010). Tältä osin tutkimukseni kytkeytyy niin sanottuun diskursiiviseen perinteeseen, joka lähestyy yleisöä ja julkisoa ensisijaisesti käsitteellisenä ongelmana (Ridell 2010). ${ }^{3}$ Teoreettisen lähtökohdan muodostaa ajatus julkiseen keskusteluun osallistuvasta julkisosta eli julkisessa tilassa keskustelevasta ihmisryhmästä. Julkison käymässä keskustelussa erilaiset näkemykset asettuvat edelleen vastakkain, selvittelemään välejään (ks. Blumer 2010 [1946]; Pietilä \& Ridell 1998; Pietilä 2010 [1999]). Tällainen käsitys julkisosta ei ole yksinomaan diskursiivisen perinteen tuotos, ja se kantaa mukanaan käsitteellisen kysymyksenasettelun ulkopuolista painolastia. Julkisuus ja julkinen keskustelu käsitteinä kytkevät julkison määritelmät laajaan yhteiskuntateoreettiseen kenttään - muun muassa habermasilaiseen ajattelutapaan ${ }^{4}$. 
Ridellin mukaan yhteiskunnallista tulokulmaa edustavat teoreetikot, kuten Habermas, kantavat huolta "ihmisten demokraattiselle yhteiselämälle välttämättömäksi nähdyn julkison kehityksestä sekä sellaisen mahdollisuuksista"(2010, 18). Kun diskursiivinen perinne siis kysyy, miten julkiso pitäisi käsittää, yhteiskunnallinen ja normatiivinen pyrkii hahmottamaan sitä, millainen julkison pitäisi olla. Vaikka olen kiinnostunut ennen kaikkea ensimmäisestä, koen välttämättömäksi myös kommentoivan julkison reunaehtojen kartoittamisen. Perustuksiltaan analyyttinen ja määritelmällinen lähtöoletukseni palautuu varsin liki Pietilän käsitystä, joka edellyttää julkison jäsenten "asioihin puuttumiselta vain sitä, että ne pyrkivät tai osallistuvat julkiseen vuorovaikutukseen ja ylittävät oman henkilökohtaisen maailman" (2010 [2006], 260). Positioni sen suhteen, "lähestytäänkö kysymystä julkisosta painottuneemmin rakenteiden kuin toiminnan suunnasta" (Ridell 2010, 18), on selvärajainen. Päärooliin nousevat kysymykset julkison toiminnallisista ulottuvuuksista, ja rakenteiden merkitys jää käsitteellisen ja analyyttisen pohdinnan kannalta toissijaiseksi. ${ }^{5}$

Herbert Blumer kuvasi aikoinaan julkisoa (toiminnalliseksi) ihmisryhmäksi, "(a) joka on kasvokkain jonkin kysymyksen kanssa, (b) joka on eri mieltä siitä, kuinka sitä on käsiteltävä, ja (c) joka on antautunut keskustelemaan asiasta" (2010 [1946], 125). Määritelmä on kestänyt aikaa, vaikka sittemmin julkison toiminnallinen määrittely onkin kytkeytynyt lähes saumattomasti yleisöön. Esimerkiksi Heikki Heikkilä ym. (2012, 131, 190) nostavat yleisön keskeiseksi toiminnan muodoksi tulkinnan, jolloin julkison rooliin asettumisessa ratkaisevaa on se, "herättävätkö median käsittelemät aiheet halua keskustella muiden ihmisten kanssa tai miettiä jatkotoimenpiteitä". Stephen Coleman ja Karen Ross $(2010,42)$ puolestaan kuvaavat julkisoa "aktiiviseksi yleisöksi". Nykymääritelmissä keskusteleva julkiso näyttäisi siis edellyttävän tulkitsevaa yleisöä. Paluu julkison käsitteellisille syntysijoille - aikaan ennen joukkoviestinnän valtakautta - muistuttaa kuitenkin varsin perustavanlaatuisesta erosta, jota Pietilä (2010 [1999], 209) Blumerin jalanjäljissä kuvaa:

Blumerilaisessa näkemyksessä on julkison, yleisön ja joukkoviestinnän suhteiden pohdinnan kannalta tärkeää, että julkiso ei määrity suhteessa joukkoviestintään vaan suhteessa siihen kysymykseen joka on kutsunut sen esiin.

Yleisön syntymä kytkeytyy siis automaattisesti joukkoviestintään (viestimeen), mutta julkison herättää henkiin joukkoviestinnän ulkopuolinen maailma - ongelma, kysymys tai asia, josta julkison jäsenet ovat eri mieltä ja johon he etsivät ratkaisua. Näkemysten välinen kamppailu saa voimansa joukkoviestinnän ulkopuolelta, vaikka median rooli keskustelun mahdollistajana onkin nykypäivänä ilmeinen: "[...] jos viestimet eivät ota asialistalleen jotain kysymystä, sen mahdollisesti kylvämä julkiso ei pääse välttämättä edes taimelle" (emt.).

Muodostavatko kommentoijat sitten tällaisen kysymyksen kylvämän julkison? Voitaneen todeta, että kommentointi toimintana itsessään näyttäisi toteuttavan julkisolle asetetun edellytyksen halusta keskustella, ylittää raja henkilökohtaisen 
maailman ja julkisen välillä. Tämän artikkelin kannalta ratkaiseva on kuitenkin jatkokysymys siitä, missä määrin kommentit todella ovat jaetun ongelman herättelemää julkiseksi miellettyä keskustelua, jota hallitsee erilaisten vastakkaisten näkemysten välienselvittely.

\section{Tapaus Talvivaara}

Sotkamolaisen kaivosyhtiö Talvivaaran kaivoksen kipsisakka-allas alkoi vuotaa marraskuussa 2012, ja altaaseen varastoitua jätevettä pääsi valumaan kaivosalueelle ja ympäröivään luontoon. Aluksi yhtiö ja paikalliset viranomaiset keskittyivät vuodon tukkimiseen ja vaikutusten minimoimiseen. Uutisoinnissa esille nousivat muun muassa kysymykset siitä, oliko kipsisakka-allas rakennettu oikein ja miksi altaassa oli laitonta jätevettä. Kun vuoto täytti kaivosalueen allaskapasiteetin, Talvivaara haki lupaa juoksuttaa niin sanottua neutraloitua jätevettä ympäröivään vesistöön. Ajankohtaiseksi muodostuivat kysymykset Talvivaaran juoksutusrajojen ja ympäristöluvan uudistamisesta. Kipsisakka-allas alkoi vuotaa uudelleen huhtikuussa 2013, ja Talvivaaran ympäristölupa uudistettiin toukokuun lopulla 2013.

Media seurasi vuotoja, juoksutuksia, lupaprosesseja, näiden vaikutuksia ja muun muassa ympäristöjärjestöjen toimintaa hyvin erilaisin ottein. Väitöstutkimukseni kokonaisaineisto koostuu kaikista ${ }^{6}$ Talvivaaraan liittyvistä uutisjutuista ja niitä seuraavista kommenteista kolmessa suomalaisessa verkkolehdessä, paikallisessa SL:ssä, maakunnallisessa KS:ssa ja valtakunnallisessa HS:ssa, aikaväliltä marraskuu 2012 toukokuu 2013. Verkkolehtien valinnassa painoarvoa sai kommentointimahdollisuus, mutta pääperustelu lehtien valinnalle on niiden merkitys omassa toiminnallisessa kontekstissaan.7 ${ }^{7}$ hteensä verkkouutisia ilmestyi SL:ssä 198, KS:ssa 275 ja HS:ssa 157. Kommentteja kertyi yhteensä noin 23000.

Tarkan keskusteluanalyysin toteuttaminen näin laajasta aineistosta ei vaikuta mielekkäältä, ja tästä syystä olen rajannut aineistosta menetelmällisen testauksen ensimmäiseen vaiheeseen jokaisen verkkolehden kommentoiduimman uutisen kommentteineen. SL:n kommentoiduin (126 kommenttia) uutinen on otsikoitu Antti Lankinen kirjoitti ministerille: "Talvivaarassa nerokkaita vain rahoitusratkaisut" (SL, 9.2.2013) (Liite 1.). KS:ssa eniten kommentteja (315 kommenttia) on kerännyt ensimmäinen vuotouutinen Jätevesivuoto 5000-600o kuutiota tunnissa (KS, 4.11.2012) (Liite 2.). HS:ssa kommentoiduin (96 kommenttia) uutinen Talvivaaran uraanipitoista vettä kulkeutunut jo kilometrien päähän (HS, 9.11.2012) (Liite 3.) ajoittuu niin ikään akuuttiin vuototilanteeseen. Vaikka analyysin kohteena on yhteensä vain kolme kommenttiketjua, puheenvuoroja kommenttien muodossa kertyy yhteensä 537, mitä pidän alustavan testauksen kannalta riittävänä. ${ }^{8}$ Analyysin toisessa vaiheessa olen ottanut tarkasteluun jokaisen verkkolehden kymmenen kommentoiduinta uutista kommentteineen. Tämän laajemman aineiston tarkastelussa olen hyödyntänyt alustavan testauksen perusteella luomaani työkalukokonaisuutta. Yhteensä uutisia toisessa aineistossa on 30 ja kommentteja 3413 (ks. Taulukko 1). 


\section{Keskusteluanalyysi: menetelmälliset raamit}

Keskustelunanalyysin lähtölaukauksena pidetään yleisesti Harvey Sacksin luentosarjoja vuosilta 1964-1972. Tutkimussuunnan perustan muodosti ja muodostaa yhä oivallus siitä, että "keskustelu ei ole kaaos eikä puhujien keskinäinen ymmärrys perustu sattumaan, vaan että vuorovaikutus on yksityiskohtiaan myöten järjestynyttä ja jäsentynyttä toimintaa”. (Hakulinen 1997a, 13) Keskustelunanalyysin tavoitteena on selvittää vuorovaikutustilanteisiin liittyviä kontekstisidonnaisia lainalaisuuksia ja normeja, jotka väistämättä ohjaavat keskustelijoiden toimintaa, mutta tulevat samalla uudistetuiksi ja muokatuiksi (esim. Heritage 1996, 234-239).

Vaikka keskustelunanalyysi on alun alkaen kehitetty puhutun kielen analysointia varten, sen käyttö kirjoitettujen keskusteluiden, kuten tietokonevälitteisen kommunikoinnin (computer-mediated communication CMC) tutkimisessa on yleistynyt (ks. esim. González-Lloret 2011), eikä menetelmä ole verkkokeskusteluidenkaan tutkimukselle vieras. Vahvana inspiraationa tämän artikkelin menetelmälliselle kokeilulle ovat toimineet Pietilän keskustelunanalyyttiset tutkimukset (2010 [2001]; 2010 [2002]a; 2010 [2002]b), joissa tutkimuskohteena ovat olleet verkon keskustelufoorumit.

Olennaista keskustelunanalyysin tutkimuskohteen kannalta on ymmärrys "vapaasta" vuorottain käytävästä keskustelusta. Käytännössä tutkittavan vuorovaikutustilanteen on täytettävä keskustelulle asetetut vuorottelun vaatimukset, joita Sacks on listannut 12 kohdan verran. ${ }^{9}$ (Hakulinen 1997b, 35). Näistä kommenttien tutkimisen kannalta keskeisimpiä ovat muun muassa vaatimukset siitä, että puhuja vaihtuu, keskustelun pituutta ei ole rajattu, eikä vuorojen sisältöä ole ennalta määritetty. ${ }^{10}$ Kommenttiketjut edustavat myös niin sanottua asynkronista keskustelua, jossa kommunikointi on ei-reaaliaikaista sekä paikasta ja ajasta riippumatonta. Keskustelunanalyysin soveltaminen tällaiseen aineistoon ei luonnistu ongelmitta, eikä kaikkia tutkimusmetodeja ole mahdollista saati mielekästä pyrkiä hyödyntämään. Koska kyseessä on menetelmällinen testaus, lähestyn kommentteja keskustelunanalyysin tyypillisimpien työkalujen, vuorottelujäsennyksen ja sekvenssijäsennyksen avulla. Listan jatkoksi kuuluisi korjausjäsennys, mutta jo alustava analyysi osoitti, ettei tämä jäsennys nouse merkittävään rooliin kommentoinnin kaltaisessa vuorovaikutustilanteessa." (ks. esim. Hakulinen 1997a, 16)

Vuorottelujäsennysten analyysi tarkastelee tutkittavaa keskustelua kahta kysymystä silmällä pitäen: "1) mistä vuorot rakentuvat, ja 2) miten vuoroja jaetaan" (Hakulinen 1997b, 36). Ensimmäisen kysymyksen merkitys jää kommenttien tarkastelussa sivurooliin, sillä kommentit näyttäytyvät varsin eksplisiittisesti yksittäisinä ja selkeinä puheenvuoroina. ${ }^{12}$ Analyysi keskittyy siis siihen, miten keskustelussa jaetaan vuoroja. Vaikka kommentoijat voivat käytännössä jättää kommenttinsa koska tahansa ja missä kohtaa ketjua tahansa, kommenteista muodostuvasta monenkeskisestä keskustelusta (ks. esim. Londen 1997) löytyy selkeitä viitteitä puheenvuorojen kohdentamisesta. Ilmiöstä, jossa "lausuma aina muotoillaan vastaanottajaa ajatellen", käytetään keskustelunanalyysissa termiä recipient design. Kommenttien 
kannalta keskeistä on se, että "[k]eskustelijat osoittavat toiminnoillaan suhtautumisensa käynnissä olevaan topiikkiin ja toistensa lausumiin" (emt.).

Sekvenssijäsennys puolestaan kuvaa sitä, miten puheenvuorot liittyvät toisiinsa ja millaisia rakenteita näistä liitoskohdista syntyy. Kahden tai useamman vuoron kokonaisuuksia, joiden välinen yhteys on tulkittavissa erityisen vahvaksi ja konventionaalistuneeksi, kutsutaan vieruspareiksi. (Raevaara 1997,75) Vieruspareista on edelleen erotettavissa etujäsen ja jälkijäsen, jotka kytkeytyvät toisiinsa tunnistettavan parityypin perusteella (Heritage 1996, 240-241; Raevaara 1997, 76). Tällaisia tyyppejä ovat esimerkiksi kysymys-vastaus, argumentti-vasta-argumentti ja pyyntö-hyväksyntä/hylkäys. Vaikka sekvenssijäsennys ja vieruspariajattelu korostavat vuorojen peräkkäisyyttä, kommenttien tarkastelussa on välttämätöntä huomioida, että toisiinsa liittyvät puheenvuorot sijoittuvat vain harvoin täysin vierekkäin. Tästä huolimatta uutisten ja kommenttien muodostamista kokonaisuuksista on mahdollista tutkia vierusparien syntymistä ja niiden merkitystä keskustelussa. Esimerkiksi Pietilä (2010 [2001]; 2010 [2002]a; 2010 [2002]b) on hyödyntänyt keskustelufoorumien tutkimuksissaan erityisesti vieruspariajattelua siitä huolimatta, etteivät viestit välttämättä asetu peräkkäin.

Vierusparien toimintaan kytkeytyy olennaisella tavalla myös jälkijäsenten preferenssijäsennys, joka määrittää jälkijäsenen suhdetta etujäseneen: "esimerkiksi pyyntöön suostuminen tai kutsun hyväksyminen ovat preferoituja jälkijäseniä (preferreds), kieltäytyminen ja torjuminen taas preferoimattomia (dispreferreds)" (Tainio 1997, 94). Alustavan analyysin perusteella kommenttiketjujen tyypillisimpiä etujäseniä ovat kannanotot, joiden jälkijäsenten toiminnalliset vaihtoehdot eli preferenssiformaatit ovat samanmielisyys ja erimielisyys (Heritage 1996, 265). Preferenssijäsennyksellä on merkittävä vaikutus vuorovaikutustilanteiden etenemiseen ja sujuvuuteen, ja kasvokkaisessa keskustelussa kulttuurinen ja sosiaalinen paine preferoitujen jälkijäsenten käyttämiseen - kuten samanmielisyyden ilmaisemiseen - on vahva.

Sanalla sanoen preferoidun formaatin toiminnot ovat yleensä affiliatiivisia, yhteisyyttä luovia, ja preferoimattoman formaatin toiminnot ovat epäaffiliatiivisia, etäännyttäviä. Preferoidun formaation toiminnot ovat yleensä sosiaalista solidaarisuutta säilyttäviä ja preferoimattoman formaatin toiminnot sitä tuhoavia. (Emt.)

Edellä kuvattujen jäsennysten ja niiden toiminnallisten ominaisuuksien perusteella olen laatinut seuraavan kysymyskokonaisuuden, jonka kautta jokaista kommenttia on tarkasteltu. Olen lähtenyt liikkeelle asetelmasta, jossa uutisen lausumat voivat edustaa etujäsentä, vaikka ne eivät eksplisiittisesti näin teekään. Määritelmällinen venytys on tarpeen, jos haluamme tarkastella kommenttien keskustelevaa suhdetta uutiseen. Kommenttien ilmeisin tarkoitus - uutisen kommentointi - puoltaa siis uutisen asettamista etujäsenen rooliin. ${ }^{13}$ 
1. Vuorottelujäsennys ja recipient design: Kenelle kommentti on kohdistettu, kuka on puhuttelun kohde?

2. Vierusparit: Onko kommentti etujäsen vai jälkijäsen? Millainen on etujäsenen tai jälkijäsenen parityyppi (esimerkiksi kysymys, kannanotto, vastaus)? Minkä jälkijäsen kommentti on (uutinen vai kommentti)?

3. Preferenssijäsennys: Onko kannanoton jälkijäsen samanmielinen vai erimielinen?

Vaikka tämän artikkelin menetelmällisen testauksen suunnannäyttäjänä voidaan pitää Pietilän tutkimuksia, lähestymistavat eroavat toisistaan monilta osin. Pietilä (2010 [2001], 404-405) muun muassa erottaa puheenvuoroista dialogisuuden muodoiksi hakemisen, virittämisen ja asettumisen, jotka tässä artikkelissa korvautuvat puhuttelun kohteella (hakeminen), etujäsenyydellä (virittäminen) ja jälkijäsenyydellä (asettuminen). Pietilän huomio on ensisijaisesti keskusteluareenoiden dialogisuuden arvioimisessa. Kommentointi ilmiönä kutsuu kuitenkin tarkastelemaan myös uutisen ja kommenttien välisiä suhteita. Näin ollen tutkimuskohteet ja niiden erot määrittävät sitä, millä tavoin keskustelunanalyysi tulee hyödynnetyksi. Tutkimalla esimerkiksi sitä, kenelle kommentoijat puheensa osoittavat, laajennan kysymystä pelkästä dialogin hakemisesta kohti hakemisen kohdetta.

Ennen varsinaista analyysia on syytä selventää varsin perustavanlaatuinen ero HS:n ja kahden muun lehden välillä. Tutkimusajanjakson aikana SL:ssä ja KS:ssa lähes kaikki kommentit on esitetty anonyymisti eli kommentoija on Vieras (SL) tai Tuntematon (KS) ja kommentin selkein tunniste on päivämäärä ja kellonaika. HS:ssa kaikkien kommentoijien on sen sijaan rekisteröidyttävä ja kommentoitava nimimerkin takaa. Vaikka nimimerkki mahdollistaa yhä tietynlaisen nimettömyyden, se vie väistämättä kommentointia ja keskustelua hahmo- tai henkilökeskeisempään suuntaan. Toisaalta on muistettava, että siinä, missä HS:n kommentoijat kohdistavat sanansa toisilleen nimimerkin avulla, SL:n ja KS:n kirjoittajat tekevät saman viittaamalla muun muassa esitetyn kommentin ajankohtaan.

\section{Menetelmällistä testausta: vuorojäsennys}

Vuorojäsennysten analyysin tavoitteena on tehdä näkyväksi sitä, millaiseksi kommentoijat kuvittelevat lukijan eli puheenvuoron kuulijan - kenen kanssa kommenteissa oikeastaan keskustellaan. Kaikista kolmesta kommenttiketjuista löytyy selkeitä kohdistuksia tietylle vastaanottavalle taholle ja vastavuoroisesti kohdistuksia, joille ei löydy selkeää kohdetta. Useimmiten epäselvienkin puhuttelujen taustalle on silti mahdollista asettaa oletus kuuntelevista "muista". Puhuttelut siis toteuttavat vuorottelujäsennystä recipient designin hengessä: kommentoijat osoittavat suhtautumisensa käynnissä olevaan keskusteluun ja muiden lausumiin.

KS, Tuntematon, 4.11.2012, 18:04

Tämä oli odotettavissa että vuotoja tulee. 
Ensimmäisen vaiheen analyysin perusteella puhuteltavat tahot on mahdollista jakaa seuraavasti:

a) uutinen ja uutisessa esiintyvät toimijat

b) uutisen ja kommenttien ulkopuoliset toimijat

c) tietyt kommentoijat

d) kommentoijat yleisesti

e) "muut".

Ensimmäiseen ryhmään kuuluvat kommentit, jotka kohdistuvat selkeästi uutisessa esitettyihin kantoihin, väitteisiin tai sisältöön ylipäätään. Seuraava kommentti on osoitettu erimieliseksi vastaväitteeksi Talvivaaran viestintäpäällikön kannanottoon, jonka mukaan vettä vuotaa kipsisakka-altaasta "puronomaisesti" (ks. Liite 2.).

KS, Tuntematon, 5.11.2012, 16:59

Todella pieni puro vain 6 milj. litraa tunnissa. Sekin arvio kuitenkin alakantissa.

Toisen puhutteluryhmän kautta keskusteluun pyritään tuomaan uusia toimijoita, joiden osallistuminen on kommentoijien mielestä tavalla tai toisella olennaista. Kohdistus on selväsanainen, kuten KS:n kommentissa, joka on osoitettu uutisen ulkopuoliselle taholle (vrt. Liite 2.).

KS, Tuntematon, 4.11.2012, 22:05

PÄÄTTÄJÄT TEKOJA ! ASIA ON VAKAVA !

Kolmannen ryhmän muodostavat sellaiset kommentit, joista pystyy varmuudella toteamaan, mihin aiemmista kommenteista puheenvuoro kohdistuu. Kommentti voi esimerkiksi pitää sisällään suoran lainauksen toisesta kommentista tai vaihtoehtoisesti vastauksen, kannan tai jatkokysymyksen, joka kohdistuu eksplisiittisesti tiettyyn esitettyyn sisältöön. SL:ssa ja KS:ssa muiden kommentteihin viitataan useimmiten kommentointiajankohdan avulla.

SL, Vieras, 10.2.2013, 14:57

10:45 < Vettä??? Vaan kun se El ole vettä (vettä juodaan). Se on puhdistamatonta kemiallista myrkkyliuosta, joka tappaa elollisen elämän...

HS:ssa vastaava puheenvuoro kohdistuu yleensä tietylle nimimerkille ja tämän kommenttiin ${ }^{14}$.

HS, 9.11.2012, Nimimerkki $H^{15}$ :

Nimimerkki G: Kulunut vuosi on ollut hyvin sateinen. Tavallisella sukankuluttajalla ei ole kovin hyvää käsitystä siitä, kuinka suurista vesimääristä Talvivaaran kaivosalueella puhutaan. näytä lisää 
Tavallisella sukankuluttajalla ei ole myöskään minkään laista käsitystä siitä, että miten jollekin voi tulla yllätyksenä, että Suomessa sataa vettä, vai menikö gobin autiomaa ja kainuun korpi sekaisin.

Neljäs puhuteltava ryhmä ovat kommentoijat yleisesti. Tämä tarkoittaa sitä, että puheenvuoro viittaa selvästi muissa kommenteissa esitettyihin kantoihin tai kysymyksiin mutta ei kohdistu tarkasti yhteen kommentoijaan - viittaus tapahtuu aiheen tasolla.

KS, Tuntematon, 4.11.2012, 17:29

näyttää olevan niin, että immeiset ei tiedä mikä rojekti lähdössä käyntiin, mutta en kerro vielä mikäse on..tuopi reilusti työpaikkoja sehän ei kaikille ole hyväksi..outellaanha vielä vuosi...

Viimeinen ja suurin ryhmä "muut" määrittyy ikään kuin vastakohtana kaikille aikaisemmille. Olennaista puhuttelujen tunnistamisessa on se, ettei kohdistusta voi selvittää sen perusteella, kuuluuko puhuteltu uutislähteisiin tai kommentoijiin. Myös seuraavassa kommentissa puhuteltu me on syytä tulkita viittaukseksi kommentoijia tai lukijoita suurempaan ihmisryhmään "muihin".

SL, Vieras, 6.2.2013, 22:49

Meille kaikille on pelastus, jos Talvivaara menee konkkaan. Mitä pikimmin sen parempi.

Joissain kommenteissa puhuttelu on suunnattu sekä "muille" että tietylle taholle. Seuraavassa esimerkissä puhuttelun kohteena ovat sekä Antti Lankinen että "muut". Lankista ei puhutella suoraan, jolloin puheenvuoro yhtä aikaa esittää "muille" kannan ja haastaa välillisesti Lankisen.

SL, Vieras, 7.2.2013, 15:13

Lankinen osoittaa vihansa työmiehille ja heidän perheilleen. Kristittyjen arvomaailma on outo ja kieroutunut jo syntyajoista alkaen.

On myös mahdollista, että puhuttelun kohde vaihtuu kesken kommentin: ensin kohdistus on tiettyyn toimijaan ja sen jälkeen "muihin" - tai päinvastoin. Esimerkiksi HS:n kommentoija Nimimerkki G puhuttelee aluksi yleisellä tasolla "muita" ja kohdistaa sen jälkeen kritiikkinsä viranomaisten uutisessa esittämiä kantoja kohtaan.

HS, 9.11.2012, Nimimerkki G:

Kulunut vuosi on ollut hyvin sateinen. Tavallisella sukankuluttajalla ei ole kovin hyvää käsitystä siitä, kuinka suurista vesimääristä Talvivaaran kaivosalueella puhutaan. [...] Suomeksi 54 miljardia litraa.

Siinä on insinööreillä hieman haastetta pumpattavana - turha on viranomaisten hurskastella taistelussa luonnonvoimia vastaan, että Talvivaaralla ei ollut lupaa varastoida jätevesiä kipsisakka-altaaseen! 


\section{Menetelmällistä testausta: vierusparit ${ }^{16}$ ja preferenssijäsennys}

Olennaista vierusparien analysoinnissa on jäsenten toiminnallisen tyypin tunnistaminen (Raevaara 1997; Heritage 1996, 240-242), eli sen määrittäminen, muodostavatko kokonaisuuden esimerkiksi kysymys-vastaus vai kannanotto/kanta-samanmielisyys/erimielisyys. Olen tyypitellyt etujäsenet ja jälkijäsenet analyysin perusteella seuraavasti (ks. Taulukko 1.):

a) etujäsenet: kanta, kysymys, kehotus, kehu, lisätieto ja muu

b) jälkijäsenet uutiseen: erimielinen tai samanmielinen kanta, jatko/välikysymys, vastaus, kanta, kehotus, lisätieto

c) jälkijäsenet kommentteihin: erimielinen tai samanmielinen kanta, jatko/välikysymys, vastaus, kanta, kehotus, lisätieto

Yksittäinen kommentti voi pitää sisällään useita ominaisuuksia sekä etujäsenenä ja jälkijäsenenä. Seuraavista esimerkeistä ensimmäinen kuvaa etujäsenen kantaa ja toinen kysymystä. Kolmas kommentti pitää etujäsenenä sisällään sekä kehotuksen että kannan.

1. Kaikki altaat ylös ja uusiksi. (KS, Tuntematon, 4.11.2012, 18:18)

2. Miten ne Talvijoen metallipitoisuudet on sinne joutuneet? Joko se bioliotusbakteeri on karannut ympäristöön ja jauhaa metallit irti koko pitäjästä? Hui!! (SL, Vieras, 7.2.2013, 20:03)

3. Soittakaa Kainuun Ely-keskukseen ja vaatikaa kovempia otteita Talvivaaran suhteen!!! Voi olla että saatte samanlaisia ympäripyöreitä vastauksia, kuin mitä minä sain, mutta mitä useampi soittaa ja vaatii asioihin muutosta ja korjausta sitä parempi. (KS, Tuntematon, 5.11.2012, 10:58)

Edellä esitetyt esimerkit kuvaavat helposti osoitettavia etujäseniä. Käytännössä etujäsenten tunnistaminen osoittautui paikoitellen varsin vaikeaksi tehtäväksi. Iso osa erityisesti KS:n ja osin SL:n puheenvuoroista vaikuttaa aiheen perusteella osallistuvan kommenttiketjussa käytäviin väittelyihin, mutta keskustelulliset ainekset uupuvat ja yksittäiset kommentit jäävät irrallisiksi. Kommentit eivät pidä sisällään eksplisiittisiä viittauksia uutiseen tai aikaisempiin kommentteihin, mutta ottavat esimerkiksi kantaa Talvivaaran toimintaan. Vaikka puheenvuorot siis periaatteessa vaikuttavat sisällölliseen tasapainoon - esimerkiksi siihen, kuinka suuri osa kommenteista vastustaa Talvivaaraa - ne eivät keskustelun osasina täytä uutisen jälkijäsenen kriteerejä. Kommentit onkin tulkittava "muille" suunnatuiksi etujäseniksi, kuten kannanotoiksi. 
KS, Tuntematon, 4.11.2012, 19:01

Kyllä nyt on tullut aika sulkea kaivos lopullisesti, koska on todettu, että nykyisillä tiedoilla sille ei olisi annettu lupaa (yle). Liotusmenetelmä ei tule jatkossakaan olemaan yhtään "vähävetisempi" kuin tähän saakka. Minne niiden vesien kanssa mahdutaan, jos toiminta jatkuu samanlaisena. Ei minnekään. Koko Suomi saastuu.

Jälkijäsenten kohdalla sama tunnistusongelma toistui sikäli, että kaikissa kommenteissa ei eksplisiittisesti osoiteta etujäsentä.

SL, Vieras, 6.2.2013, 20:33

Hyvä Antti 1,05

SL, Vieras, 6.2.2013, 21:34

Huomenna $0,99-1,00$. Ostolaidalle

Ensimmäinen kommentti pitää etujäsenenä sisällään kehun "Hyvä Antti", joskin tässä tapauksessa kyse lienee ironiasta, eräänlaisesta antikehusta. Kommentin toinen osa 1,05 viittaa Talvivaaran osakkeiden laskevaan arvoon, ja sen voi tällaisena tulkita kannaksi. Jälkimmäinen kommentti puolestaan tarttuu tähän, ja jatkaa aiemman kommentoijan aloittamaa keskustelua. Yhteisten piirteiden perusteella kommentti on siis syytä tulkita jälkijäseneksi aikaisemmalle puheenvuorolle, vaikka preferenssijäsennys jääkin epäselväksi.

\section{Menetelmällisen testauksen alustava anti: Paljon kysymyksiä, vähän vastauksia}

Tarkasteluun otetut kolme kommenttiketjua eroavat huomattavasti sen suhteen, kenen kanssa kommentoijat asettuvat selkeään vuoropuheluun (Taulukko 1.). SL:ssa puhuttelujen kohteet vaihtelevat tasaisimmin. Varsinkin ketjun alussa kommentoijat osoittavat sanansa suoraan Antti Lankiselle, mutta kokonaisuudessa puhutelluimmiksi nousevat tietyt kommentoijat ja "muut". KS:ssa "muiden" osuus on varsin hallitseva, ja vaihtelu puhuttelujen kohteiden välillä jää vähäiseksi. HS:ssa merkittävä osa puheenvuoroista kohdistuu tiettyihin kommentteihin, mitä selittänee nimimerkkien käyttö. Kaiken kaikkiaan vuorottelujäsennyksen osalta silmiinpistävää on uutisen ja uutislähteiden pieni rooli oletettuina keskustelukumppaneina.

Vierusparien osalta kaikissa kolmessa kommenttiketjussa toistuu vastaamattomien kysymysten ilmiö. Näkyvintä tämä on KS:ssa, jossa etujäsenissä esitettyjä kysymyksiä ja jälkijäsenten jatkokysymyksiä on yhteensä 111, mutta vastauksia vain 13. SL:ssa vastaavat luvut ovat 48 kysymystä ja 13 vastausta ja HS:ssa 43 kysymystä ja 5 vastausta. (Ks. Taulukko 1.) 
Taulukko 1. Kommentoiduin uutinen. Kokonaisanalyysi.

\begin{tabular}{|c|c|c|c|c|}
\hline & & SL (\%) & KS (\%) & HS (\%) \\
\hline \multirow[t]{5}{*}{ Puhuttelun kohde } & UUTINEN/ UUTISLÄHDE & 10,3 & 21,6 & 13,5 \\
\hline & KOMMENTOIJA & 33,3 & 15,9 & 57,3 \\
\hline & KOMMENTOIJAT YL. & 20,6 & 15,6 & 5,2 \\
\hline & "MUUT" & 30,2 & 54,0 & 41,7 \\
\hline & ULKOPUOLINEN KOHDE & 11,9 & 15,9 & 8,3 \\
\hline \multirow[t]{6}{*}{ Etujäsen } & KANTA & 30,2 & 39,7 & 32,3 \\
\hline & KYSYMYS & 13,5 & 22,2 & 16,7 \\
\hline & KEHOTUS & 0,0 & 10,2 & 3,1 \\
\hline & KEHU & 10,3 & 2,5 & 0,0 \\
\hline & LISÄTIETO (LINKKI) & 1,6 & 13,3 & 5,2 \\
\hline & MUU & 0,8 & 1,3 & 0,0 \\
\hline \multirow[t]{7}{*}{ Uutisen jälkijäsen } & ERIMIELINEN & 15,1 & 6,7 & 5,2 \\
\hline & SAMANMIELINEN & 11,9 & 1,0 & 1,0 \\
\hline & JATKO/VÄLIKYSYMYS & 0,0 & 4,4 & 2,1 \\
\hline & VASTAUS & 0,0 & 0,0 & 0,0 \\
\hline & KANTA & 2,4 & 1,9 & 5,2 \\
\hline & KEHOTUS & 0,0 & 0,3 & 0,0 \\
\hline & LISÄTIETO & 0,0 & 0,0 & 0,0 \\
\hline \multirow{7}{*}{ Kommentin jälkijäsen } & ERIMIELINEN & 47,6 & 20,3 & 53,1 \\
\hline & SAMANMIELINEN & 4,0 & 9,5 & 10,4 \\
\hline & JATKO/VÄLIKYSYMYS & 23,0 & 8,6 & 26,0 \\
\hline & VASTAUS & 10,3 & 4,1 & 5,2 \\
\hline & KANTA & 15,9 & 14,3 & 45,8 \\
\hline & KEHOTUS & 0,0 & 1,9 & 4,2 \\
\hline & LISÄTIETO & 0,0 & 1,6 & 12,5 \\
\hline \multicolumn{2}{|l|}{ Kommentteja yhteensä } & $(N=) 126$ & $(\mathrm{~N}=) 315$ & $(N=) 96$ \\
\hline
\end{tabular}

Yksittäinen kommentti voi pitää sisällään useita ominaisuuksia.

Vastausten vähyys johtunee ainakin osittain siitä, että - kuten todettua - iso osa kommenteissa erityisesti KS:ssa ja osittain SL:ssa jää irrallisiksi puheenvuoroiksi. Niissä esitetyt kysymykset näyttäytyvät ikään kuin retorisina.

KS, Tuntematon, 5.11.2012, 18:35

Altaat tyhjenee ja kassa on tyhjä vuoden loppuun mennessä, kuten toimitusjohtaja sanoi. Kuka korvaa vahingot? Osakkeenomistajat vastuuseen rahoittamaan ympäristön puhdistusta?

Toinen syy yleiseen vastaushaluttomuuteen piilee todennäköisesti siinä, että kysymykset on osoitettu kommenttien ulkopuolelle, esimerkiksi uutislähteille. Tämä ei kuitenkaan estä kaikkia kommentoijia vastaamasta. Erityisesti SL:ssa Lankisen puolesta vastaaminen on tyypillistä.

SL, Vieras, 7.2.2013, 10:24

Antti, saanko minä ohjata sinulle meidän perheen 200 oooe lainan lainanlyhennykset kun olet puolisoltani työpaikkaa alta viemässä? 


\section{SL, Vieras, 8.2.2013, 09:34}

"Antti, saanko minä ohjata sinulle meidän perheen 200 oooe lainan lainanlyhennykset kun olet puolisoltani työpaikkaa alta viemässä?"

Et saa, oikea osoite on P.Perä Espoo jos maksumiestä lainallesi haluat!! [...]

Vaikka kysymys-vastaus-vieruspareja syntyy kommenttiketjuissa vähän, kantaaottavien jälkijäsenten määrä viestii pyrkimyksestä vuoropuheluun (Taulukko 2.). Puhuttelujen kohteiden perusteella on järkeenkäypää, että jälkijäseniä syntyy erityisesti kommenteille ja uutisen jälkijäsenten osuus jää pieneksi. SL:ssa tähän rooliin asettuu kuitenkin huomattavan suuri osa kommenteista, vaikka selkeitä puhutteluja uutislähdettä kohtaan on vähän. Tätä selittänee Lankisen väitteiden luonne. Tyypillisestä uutistekstistä poiketen Lankinen ilmaisee varsin suoraan mielipiteensä Talvivaarasta (ks. Liite 1.), mikä synnyttää pienimuotoisen eri- ja samanmielisten jälkijäsenten ryöpyn. HS:n kommenttiketjua hallitsee puolestaan jälkijäsenyys suhteessa kommentteihin, mikä johtunee nimimerkkien käytöstä. Nimimerkit eivät kuitenkaan yksin ohjaa kommentointia tähän suuntaan, sillä myös SL:ssa enemmistö (55,6 \%) kommenteista on muihin kommentteihin suhteutuvia jälkijäseniä. KS:ssa jälkijäsenyys on kaiken kaikkiaan pienessä roolissa, ja etujäsenten rooli vaikuttaa varsin merkittävältä.

Taulukko 2. Kommentoiduin uutinen. Etujäsenyys, jälkijäsenyys ja preferenssijäsennykset erimielisyys/samanmielisyys.

\begin{tabular}{|l|r|r|r|}
\hline & SL (\%) & KS (\%) & HS (\%) \\
\hline Puhuttelun kohde: & & & 13,5 \\
UUTINEN & 10,3 & 21,6 & 62,5 \\
KOMMENTTI & 54,0 & 31,4 & 50,0 \\
MUUT & 41,0 & 69,8 & 33,3 \\
\hline Etujäsen & 44,4 & 65,4 & 7,3 \\
\hline Uutisen jälkijäsen, joista & $\mathbf{2 7 , 0}$ & 7,9 & $\mathbf{7 1 , 4}$ \\
ERIMIELINEN & 55,9 & $\mathbf{8 4 , 0}$ & 14,3 \\
SAMANMIELINEN & 44,1 & 12,0 & $\mathbf{6 3 , 5}$ \\
\hline Kommentin jälkijäsen, joista & 55,6 & 31,2 & $\mathbf{8 3 , 6}$ \\
ERIMIELINEN & $\mathbf{8 5 , 7}$ & $\mathbf{6 7 , 4}$ & 16,4 \\
SAMANMIELINEN & 7,1 & 31,6 & $(\mathrm{~N}=) 96$ \\
\hline Kommentteja yhteensä & $(\mathrm{N}=) 126$ & $(\mathrm{~N}=) 315$ & 9 \\
\hline
\end{tabular}

Yksittäinen kommentti voi pitää sisällään useita ominaisuuksia.

Taulukossa 2. silmiinpistävää on jälkijäsenten erimielisyyden volyymi kaikissa kolmessa lehdessä. SL:ssa erimielisyys korostuu erityisesti suhteessa muihin kommentteihin, ja uutisen jälkijäsenten preferenssijäsennysten välillä vallitsee jonkinlainen tasapaino. KS:ssa lukemat ovat päinvastaiset: erimielisyys hallitsee suhteessa uutiseen, ja kommenttien jälkijäsenissä erimielisyyden osuus on hieman pienempi. HS:ssa erimielisyys vaikuttaa luonteenomaiselta sekä uutisten että kommenttien jälkijäsenille. 
Samanmielisyys ei silti kerro esimerkiksi vastakkaisten kantojen hyväksymisestä, vaan se ilmenee lähinnä tukena jaetulle kannalle. Myötäilevät puheenvuorot asettuvat siis korostamaan tiettyä näkemystä sen sijaan, että niissä osoitettaisiin oman näkemyksen muuttuneen uutisessa tai kommenteissa esitettyjen argumenttien perusteella.

Jälkijäsenten määrän ja preferenssijäsennysten avulla on mahdotonta tutkia sitä, missä määrin kommentit ketjuuntuvat yksittäisen etujäsen-jälkijäsen-vierusparin ylittäviksi keskusteluiksi. Pareja on siis tarkasteltava erikseen. Tarkan lähiluvun perusteella KS:n 315 kommentin joukosta vierusparien linkittymisestä ei löydy ainuttakaan esimerkkiä. SL:n kommenttiketjusta pidempiä vuoropuheluita syntyy harvakseltaan. Olen merkinnyt seuraavaan esimerkkiin kommenttien roolin osana keskustelua.

\section{ETUJÄSEN: "muille" osoitettu KANTA}

SL, Vieras, 7.2.2013, 15:13

Lankinen osoittaa vihansa työmiehille ja heidän perheilleen. Kristittyjen arvomaailma on outo ja kieroutunut jo syntyajoista alkaen.

\section{JÄLKIJÄSEN: JATKOKYSYMYS, joka pitää sisällään ERIMIELISEN kannan toista kommenttia kohtaan}

SL, Vieras, 7.2.2013, 15:57

"(Vieras)7.2.2013 15:13"

"...osoittaa vihansa..."

Miten perustelet kommenttisi?

Eikö tuollainen kommentti ole jo kunnianloukkaus henkilöä kohtaan?

\section{JÄLKIJÄSEN: VASTAUS toisessa kommentissa esitettyyn jatkokysymykseen}

SL, Vieras, 7.2.2013, 20:42

Lankinen kertoo olevansa yksi niistä henkilöistä, jotka toivovat Talvivaaran toiminnan päättymistä

(Vieras) $\quad 7.2 .2013 \quad 15: 57$

"(Vieras)7.2.2013 15:13"

"...osoittaa vihansa..."

Miten perustelet kommenttisi?

Eikö tuollainen kommentti ole jo kunnianloukkaus henkilöä kohtaan?

HS:ssa vastaavaa keskustelua kehkeytyy huomattavasti enemmän. Valtaosa erityisesti kommenttiketjun loppuosasta pitää sisällään kahden tai useamman kommentoijan vuoropuhelua - eräänlaista pienoiskeskustelua, jota hallitsee vastakkaisten kantojen esittäminen vuorotellen. Tällaista "peräkkäisten kannanottojen muodostamaa jaksoa on 
nimitetty myös vuoroketjuksi [...], joka on rakenteeltaan vierusparia löyhempi toisiinsa liittyvien vuorojen sekvenssi" (Raevaara 1997, 77). Osa kommentoijista pyrkii myös pitämään nämä ketjut "kahdenkeskisinä". Sama nimimerkki voi esimerkiksi jättää usean peräkkäisen kommentin, joista jokaisessa hän vastaa eri nimimerkille eli pitää yhtäaikaiset keskustelut erillään. Tästä huolimatta myös HS:ssa kommentoijat puuttuvat muiden käymiin keskusteluihin vastaamalla vaikkapa toiselle nimimerkille esitettyyn kysymykseen.

Vaikka nimimerkin merkitys vaikuttaa ensimmäisen vaiheen analyysin perusteella huomattavalta, pelkkä nimimerkki tai kommentointikäytäntö ei riitä perusteluksi lehtien välisille eroille. SL:n ketjun alussa iso osa kommenteista on osoitettu suoraan uutisen puhujalle eli Antti Lankiselle (ks. Taulukko 1.), mutta kun uutisen puhuja ei ymmärrettävästi osallistu keskusteluun eikä näin ollen vie sitä eteenpäin, kommentoijat pyrkivät enenevässä määrin käymään keskustelua toistensa kanssa. KS:ssa valtaosa kommenteista jää sen sijaan yksittäisiksi etujäseniksi, jotka kohdistuvat epäselvästi "muille". Taustalla voi vaikuttaa muun muassa kommenttien volyymi: keskustelijoita ja puheenvuoroja on yksinkertaisesti liikaa, ja vain varsin provokatiiviset tai selkeät kannat tuottavat jälkijäseniä. Ensimmäisen analyysivaiheen perusteella uutisten roolia on joka tapauksessa syytä tutkia tarkemmin - uutiset etujäseninä tai useiden etujäsenien joukkona voivat herättää varsin erilaista kommentointia. SL:n esimerkkiuutinen on sikäli poikkeuksellinen, että siinä puheenvuoro on yksinomaan Lankisella, joka omassa asemassaan esittää varsin vahvoja kantoja (ks. Liite 1.). KS:n uutisessa puhujia on useita - pääosin viranomaisia - ja heidän esittämänsä kannat ovat muutamaa poikkeusta lukuun ottamatta toteavia, lähes neutraaleja (ks. Liite 2.). HS:ssa kaikki uutisen lähteet ovat viranomaisia, ja esitetyt kannat ovat niin ikään toteavia. Voidaanko siis olettaa, että tavanomaisesta poikkeava uutislähde saa aikaan uutiseen suhteutuvia jälkijäseniä ja "heikot" kannat puolestaan typistävät keskustelun joko yksittäisten etujäsenten vyöryksi (KS) tai kommentoijien väliseksi kaksintaisteluksi (HS)?

\section{Menetelmällisen testauksen laajentaminen: jälkijäsenyys ja kannanottojen volyymi}

Testiluonteisen analyysin rohkaisemana keskityn tutkimuksen toisessa vaiheessa vuorottelujäsennykseen (puheenvuorojen kohdistamiseen), selkeiden etujäsenten ja jälkijäsenten tunnistamiseen sekä kantaa ottavien jälkijäsenten preferenssijäsennysten nimeämiseen. Aineisto käsittää kaikkien lehtien kymmenen kommentoiduinta uutista. Tässä vaiheessa sisällytin ryhmään "muut" myös uutisen ulkopuoliset tahot, eli jaoin kommentin puhuttelukohteet kolmeen selkeään ryhmään: uutinen, kommentit, muut. Analyysin tavoitteena oli selvittää,

a) onko kommentti suunnattu (uutisen herättämänä) etujäsenenä a) muille vai kohdistuuko se etu- tai jälkijäsenenä b) uutiseen tai c) muihin kommentteihin tai niiden synnyttämään keskusteluun?

b) onko tämä jälkijäsenen kommentointisuhde uutiseen tai kommenttiin erimielinen, samanmielinen tai molempia? ${ }^{17}$ 
Seuraava KS:sta valittu kommentti on esimerkki muille (etujäsenenä) suunnatusta puheenvuorosta. Se ei itsessään vastaa uutisessa esitettyihin kantoihin, eikä kohdistu selväsanaisesti millekään taholle, vaikka kommentin esittämät kannat muun muassa Talvivaaran "pörssiläisistä" ja lisätieto suuryhtiöiden veronmaksusta ovat saaneet pontimensa uutisesta.

KS, Tuntematon, 4.11.2012, 22:14

On aivan sama mitä järki ja ymmärrys sanoo, se ei vaikuta Talvivaaran "pörssiläisiin" mitään. Vaikka kaikki ympäriltä tuhoutuu, niin osakkeiden tuotot on ensisijaisesti tärkeitä ja kuuroille korville kaikuu ympäristökansalaisten julkituomat haitat. Onhan se kuvaavaa asioiden laita täällä Suomessa, kun Nokia ja Finnair ym. eivät maksa veroja maahansa joka on tukenut ja syöttänyt niihin tähtitieteellisiä summia jotta ne "pystyssä pysyisi".

HS:sta poimittu esimerkki kuvaa puolestaan erimielisyyttä toista kommenttia kohtaan. Kommentoija kohdistaa puheenvuoronsa toiselle nimimerkille verkkolehden oman vastausmekanismin ja tarkan lainauksen avulla.

HS, 8.11.2012, Nimimerkki M:

Nimimerkki D: Jo menee turhan kiistelyn puolelle koko ketjun kirjoittajien mielipiteet. Jos kaivostoiminta hoitaa hommansa asianmukaisesti, ei jatkuvista möhläyksistä tarvitsisi kärsiä. näytä lisää

Ymmärrän hyvin myös kaivosteollisuuden tarpeellisuuden työpaikkojen ylläpitäjänä, mutta miksi turvallisuusmääräyksiä ei noudateta? Miksi myrkylliset lietteet välisijoitetaan avoaltaisiin, mhini niiden on tarkoitus mennä? Miksi ydinvoimaloita suunnitellaan, vaikka ei ole tietoa, mahtuvatko ydinjätteet mihinkään?

Mitä määräyksiä ja lupaehtojen noudattamatta jättämisiä Talvivaaran laitoksella on? Jos Talvivaara saa luvan uraanin talteenottoon, niin uraani"ongelma" poistuu, vai mitä? Ymmärtääkseni avoaltaiden vesiä on tarkoitus jatkokäyttää prosessissa. Ydinjätteet kyllä mahtuvat. Varastointitilasta ei ole mitään puutetta. Nekin voidaan tulevaisuudessa jatkokäyttää. Nyt niistä vain muutama \% on hyödynnetty.

Kolmas esimerkki pitää sisällään sekä erimielisen kannan aikaisempaan kommenttiin että uutislähteen suoran puhuttelun. Uutislähteenä on perussuomalaisten valtuustoryhmän jättänyt paikallispoliitikko Tommi Heikkinen, jolle suunnattu osuus puheenvuorosta ei kuitenkaan ilmennä eri- tai samanmielisyyttä, sillä kyseessä on kehotus.

$S L$, Vieras, 22.5.2013, 16:06

milloin on sdp ollut työtä tekevien puolella nytkin ihalainen työministerinä homma vaan huononee mieti tommi tarkkaan kenen kelkkaan lähdet terv kajaanista 
Uutisen ja kommentin suhde vaikuttaa kaiken kaikkiaan varsin monimutkaiselta. Vain pieni osa kommentoijista osoittaa suorasanaisesti eri- tai samanmielisyytensä uutisessa esitettyjä kantoja kohtaan. Huomattavasti tavanomaisemmalta vaikuttaa sen sijaan kannan ilmaiseminen välillisesti muille suunnatun etujäsenen avulla. (Ks. Taulukko 3.) Uutisessa esitetyt kannat tai tahot tulevat myös usein arvioiduksi kolmannessa persoonassa (hän, se, he tai ne) sen sijaan, että puhuttelu kohdistuisi suoraan tietylle taholle tai tiettyyn esitettyyn kantaan. Erityisen tyypillisiä nämä muille suunnatut etujäsenet ovat sellaisten uutisten perässä, joissa ei esitetä suoria kantoja tai lähteenä on varsin tavanomainen taho, esimerkiksi viranomainen tai Talvivaaran edustaja (ks. Taulukko 3.). Vastaavasti uutisissa, joissa puhujana on esimerkiksi luonnonsuojelija Antti Lankinen (SL), Talvivaaran toimitusjohtaja Pekka Perä (KS) tai ympäristöministeri Ville Niinistö (HS) ja joissa puhuja ottaa selvästi kantaa, yhä useampi kommentoija asettuu uutisen jälkijäseneksi.

Seuraavassa esimerkissä SL:n kommentoija arvioi Talvivaaraa, ympäristöliike Stop Talvivaaraa ja uutisen puhujaa arkkipiispa Leoa muille kohdistetussa etujäsenessä (ks. tekijä). Kommentti ei siis asetu erimieliseen suhteeseen uutisen kanssa, vaikka tällainen kritiikki rivien välistä olisikin mahdollista tulkita.

\section{$S L$, Vieras, 1.3.2013, 07:41}

Oho, väkevä veto Talvivaaran väeltä. Jos Stop Talvivaaran porukka nyt meinaa pärjätä taikaviittaa kantavalle arkkipiispalle, on heidän saatava vähintään jediritarit omalle puolelleen talvivaaraa vastustamaan.

Taulukko 3. Analyysin toinen vaihe. Kymmenen kommentoiduinta.

\begin{tabular}{|c|c|c|c|c|c|c|c|c|c|}
\hline & $\begin{array}{l}\text { SL (\%) } \\
\text { kaikki }\end{array}$ & $\begin{array}{r}\text { KS (\%) } \\
\text { kaikki }\end{array}$ & $\begin{array}{r}\text { HS (\%) } \\
\text { kaikki }\end{array}$ & $\begin{array}{r}\text { SL (\%) } \\
\text { alin }\end{array}$ & $\begin{array}{r}\text { KS (\%) } \\
\text { alin }\end{array}$ & $\begin{array}{r}\text { HS (\%) } \\
\text { alin }\end{array}$ & $\begin{array}{r}\text { SL (\%) } \\
\text { ylin }\end{array}$ & $\begin{array}{r}\text { KS (\%) } \\
\text { ylin }\end{array}$ & $\begin{array}{r}\text { HS (\%) } \\
\text { ylin }\end{array}$ \\
\hline $\begin{array}{l}\text { Puhuttelun kohde: } \\
\text { UUTINEN }\end{array}$ & 31,1 & 25,6 & 20,2 & 20,7 & 15,4 & 4,4 & 53,5 & 47,3 & 36,5 \\
\hline KOMMENTTI & 33,9 & 27,0 & 55,8 & 8,6 & 19,9 & 44,3 & 55,9 & 33,5 & 76,1 \\
\hline MUUT & 58,3 & 72,8 & 41,2 & 20,6 & 65,9 & 20,9 & 91,2 & 83,3 & 54,4 \\
\hline Etujäsen & 60,7 & 72,9 & 38,7 & 39,8 & 64,1 & 19,4 & 90,6 & 83,9 & 54,4 \\
\hline Uutisen jälkijäsen & 24,4 & 8,9 & 11,2 & 15,4 & 1,9 & 1,5 & 50,5 & 18,4 & 27,9 \\
\hline ERIMIELINEN & $76,0^{*}$ & $80,1^{*}$ & $82,7^{*}$ & $2,6^{* *}$ & $1,2^{\star \star}$ & $1,5^{\star *}$ & $48,4^{\star *}$ & $15,7^{\star * *}$ & $24,4^{* *}$ \\
\hline SAMANMIELINEN & 23,6 * & $20,5^{*}$ & $20,2^{*}$ & 0,0 ** & $0,0^{* *}$ & 0,0 ** & $11,9^{\text {** }}$ & $7,6^{\star *}$ & $7,8^{\star *}$ \\
\hline Kommentin jälkijäsen & 33,8 & 25,1 & 55,7 & 7,5 & 18,3 & 42,9 & 56,9 & 31,2 & 76,1 \\
\hline ERIMIELINEN & $76,7^{*}$ & $72,8^{*}$ & $82,6 *$ & $6,5^{\star *}$ & $8,8^{* *}$ & $35,3 * *$ & $47,6^{\star \star}$ & $25,4^{* *}$ & $68,7^{* *}$ \\
\hline SAMANMIELINEN & $22,7^{*}$ & $22,3^{*}$ & $22,6^{*}$ & $1,3 * *$ & $1,6^{* *}$ & $3,7^{\star \star *}$ & $19,3^{\star \star}$ & $9,5^{\star \star}$ & $21,6^{\star *}$ \\
\hline $\begin{array}{l}\text { Kommentteja } \\
\text { yhteensä }\end{array}$ & 938 & 1803 & 672 & - & - & - & - & - & - \\
\hline
\end{tabular}

*Osuus kaikista uutisen/kommenttien jälkijäsenistä

**Alin/ ylin osuus yksittäisen kommenttiketjun kaikista kommenteista

Yksittäinen kommentti voi pitää sisällään useita ominaisuuksia. 
Kaiken kaikkiaan KS:ssa selkeä enemmistö kommentoijista puhuttelee muita, ja uutiseen ja kommentteihin kohdistuu molempiin noin neljännes puheenvuoroista. SL:ssa jakauma on hieman tasaisempi, vaikka muiden osuus puhutelluista on vielä varsin suuri. Ainoastaan HS:ssa yli puolet kommenteista kohdistuu muihin kommentteihin ja alle puolet muille. Uutisen osuus puhuttelun kohteena jää HS:ssakin vähäiseksi. Huomionarvoista Taulukon 3. perusteella on myös se, missä määrin kommentit asettuvat etujäseniksi sekä SL:ssa että KS:ssa. Ero, joka kommenttiketjujen välillä ensimmäisessä vaiheessa ilmeni (ks. Taulukko 2.), vaikuttaisi kytkeytyvän yksittäisiin uutiseen ja niiden puhujiin. Kun uutisen lähteenä on esimerkiksi paikallinen luonnonsuojelija tai kaivoksella vieraileva arkkipiispa, keskustelua syntyy suhteessa uutiseen (Taulukko 3.), mutta laajemmassa tarkastelussa SL:n kommentoijat ottavat eniten kantaa etujäsenten kautta. KS:ssa jälkijäsenten määrä on huomattavasti pienempi suhteessa etujäsenten lukumäärään, ja ainoastaan HS:ssa jälkijäseniä on enemmän kuin etujäseniä.

Vaikka toisen vaiheen analyysi tukee edellä tehtyä havaintoa kannanottojen jälkijäsenten hallitsevasta erimielisyydestä, saman- ja erimielisyyden suhde ei loppujen lopuksi varioi siinä määrin, kuin alustava analyysi antaa ymmärtää (vrt. Taulukot 2. ja 3.). Kaikissa lehdissä erimielisyyden osuus on selvästi suurempi kuin samanmielisyyden, ja tämä suhde pysyy jokseenkin samanlaisena sekä uutiseen että kommentteihin kohdistuvissa jälkijäsenissä. (Taulukko 3.) Erimielisyys näyttäytyy siis kommentoinnin ominaisuutena, eikä niinkään keskusteluun kytkeytyvänä toiminnallisena piirteenä.

Kokonaisuudessaan laajempi analyysi vahvistaa tulkintaa nimimerkin vaikutuksesta kommentointikulttuurille: nimimerkit edistävät kommentoijien keskinäistä vuoropuhelua, ja nimettömyys puolestaan tuottaa yksittäisiä etujäseniä, jotka eivät välttämättä herätä lainkaan jälkijäseniä. Lisäksi kommentointi-ilmiötä näyttäisi hallitsevan erimielisyys, joka läpäisee niin uutiseen kuin kommentteihinkin kohdistuvat puheenvuorot. Näistä havainnoista huolimatta keskustelun kannalta erityiseen rooliin nousevat verkkouutisten lähteet ja sisällöt, joiden merkitys on näkyvintä SL:n ja KS:n aineistoissa.

\section{Menetelmällisen testauksen anti: vastauksia ja ongelmakohtia}

Menetelmällisen testauksen tuloksia on ensi alkuun syytä peilata lähtöoletukseen, jonka mukaan keskustelunanalyysin tavoitteena on selvittää niitä vuorovaikutustilanteiden kontekstisidonnaisia lainanalaisuuksia ja normeja, jotka vaikuttavat keskustelijoiden toiminnan taustalla (esim. Heritage 1996, 234-239). Todettakoon, että kommentointi keskustelun muotona näyttäisi pitävän sisällään tiettyjä kontekstiin kytkeytyviä toimintatapoja. Tätä toiminnallista kontekstia määrittää vähintään kolme seikkaa: a) kommentointialustaan liittyvät toimintaehdot, kuten nimimerkin käyttö, b) uutisaiheen ja uutisen toimijoiden suhde verkkolehden oletettuihin lukijoihin ja kommentoijiin, sekä c) vakiintuneiksi muodostuneet kommentoinnin tavat, kuten puheenvuoron kohdistaminen tietyn tahon sijaan yleisemmälle tasolle (esim. KS). 
Näin ollen edellä kuvattu menetelmällinen testaus osoittaa, että keskusteluanalyyttiset jäsennykset toimivat tietyiltä osin myös kommenttiketjujen tutkimisessa. Käyttökelpoisimmilta analyyttisista työkaluista vaikuttavat vuorottelujäsennys ja recipient design, eli puhuttelun kohteen määrittely. Puheenvuoron kohdistumisen perusteella pystyy tutkimaan muun muassa sitä, kenen kanssa kommentoijat keskustelevat tai haluaisivat keskustella. Sekvenssijäsennykseen kytkeytyvien vierusparien osalta olennaisia löydöksiä saadaan siitä, miten keskustelua syntyy ja miten se pysyy yllä. Etujäsenet kutsuvat eri tavoin puhuttelun kohteita mukaan keskusteluun, ja jälkijäsenet asettuvat osaksi tätä vuoropuhelua. Yhdessä puhuttelun kohteen analysoinnin kanssa etu- ja jälkijäsenten roolien tarkastelu paljastaa muun muassa sen, milloin uutisen sisältö synnyttää vuoropuhelua kommentoijien ja uutisen välillä ja milloin keskustelu käydään lähinnä kommentoijien kesken tai sitä ei juurikaan synny. Tasapaino vierusparien osien välillä ei kuitenkaan sellaisenaan kerro keskustelun etenemisestä, sillä yksittäinen kommentti voi synnyttää useita jälkijäseniä tai jäädä yksittäiseksi puheenvuoroksi, kuten erityisesti KS:n kommenttiketjuissa näyttäisi tapahtuvan. Vaikka kommenttiketjuista on myös mahdollista paikantaa kahden puheenvuoron ylittäviä pienoiskeskusteluja, niiden rooli kokonaisuudessa jää SL:n ja KS:n osalta pieneksi. HS:ssa nimimerkkien ohjaama kommentointikulttuuri sen sijaan ylläpitää tällaisia kahden tai useamman kommentoijan välisiä keskusteluita. Jälkijäsenten preferenssijäsennyksen avulla voi edelleen selvittää, millainen keskustelun sävy on ja millaiseen rooliin kommentoijat asettuvat.

Kuvatut työkalut pitävät sisällään myös erinäisiä ongelmakohtia. Esimerkiksi vuorottelujäsennyksen muita puolia, kuten vuorojen jakamisen sujuvuutta ja taukoja, on mahdotonta soveltaa kommenttiketjuihin. Analyysissa hyödynnetty puhuttelun kohteen tarkastelu pitää sekin sisällään haasteita: kohde jää usein epäselväksi, ja vaikka käsitys "muista" vie analyysia eteenpäin, keskustelun osapuolet jäävät hahmottomiksi. Vierusparien osalta merkittävin haaste liittyy tunnistamiseen. Etujäsenten ja jälkijäsenten parityypit ovat itsessään vaikeasti määriteltäviä, vaikka esimerkiksi suora kysymys tai selkeä vastaus on kommentista helppo osoittaa. Analyysin lopputulokseen vaikuttaa merkittävästi myös se, tulkitaanko uutinen usean etujäsenen rykelmäksi. Jälkijäsenten preferenssijäsennyksen suhteen ongelmia on sen sijaan huomattavasti vähemmän. Eri- ja samanmielisyyden hahmottaminen luonnistuu, kun tiedossa on selvä etujäsen. Jos suhde on epäselvä, myös preferenssijäsennys jää todennäköisesti mysteeriksi. Vaikka eri- ja samanmielisyyden analysointi on suhteellisen vaivatonta, analyysin anti jää ristiriitaiseksi. Se, että kommenttiketjuja hallitsee esimerkiksi erimielisyys, ei itsessään kerro vielä siitä, miksi näin on ja mistä tämä erimielisyys oikeastaan kielii. Lisäksi osa kommenteista pitää sisällään kielellisiä elementtejä, jotka vaikeuttavat tulkintaa, sekä sellaisia viittauksia uutisen ulkopuolisiin tapahtumiin, jotka eivät ole yleisesti tiedossa ja näin ollen tutkijan tavoitettavissa.

Kokonaisuudessaan keskustelunanalyysin vaiheet toivat paremmin esille uutisen ja kommenttien suhdetta kuin kommenttien suhdetta toisiinsa. Toisen vaiheen perusteella uutisen lähde ja aihe vaikuttavat selvästi siihen, missä määrin uutiseen kohdistuu puheenvuoroja. Uutisaiheen merkitystä sille, miten kommentoijat kommentoi- 
vat toisiaan, on vaikeampi havainnoida (vrt. Taulukko 3 ja Liite 4.). Edellä kuvatussa analyysissa ei siis pystytty riittävästi huomioimaan kommenttien sisällön merkitystä. Kommentoijien motiiveista ja keskustelun merkityksestä on niin ikään vaikea esittää selvää tulkintaa, ja keskustelunanalyysi vaikuttaisikin kaipaavan rinnalleen esimerkiksi diskurssianalyyttisia menetelmiä.

\section{Lopuksi: kommentit julkisoiden keskusteluna}

Tämän artikkelin tavoitteena on ollut selvittää, voiko kommentoinnin käsittää julkisen keskustelun muodoksi ja julkisona toimimiseksi. Olennaista on siis pohtia sitä, missä määrin tämä julkinen toiminta on keskustelua, jonka on synnyttänyt henkilökohtaisen elämänpiirin ylittävä jaettu ongelma (ks. Pietilä 2010 [2006], 260), ja missä määrin tässä keskustelussa käydään vastakkaisten näkemysten välistä vuoropuhelua.

Keskustelunanalyysin perusteella kommentoinnista on mahdollista löytää keskustelullisia piirteitä, eli valtaosa kommenteista asettuu ainakin teoreettisella tasolla osaksi konkreettista keskustelua. Julkison kannalta varsin keskeiseksi muodostuu kysymys siitä, kenen kanssa kommentoijat pyrkivät keskustelemaan. Voidaan nimittäin kysyä, onko julkison kannalta olennaisempaa, että kommentoijat keskustelevat selvästi "jonkun" kanssa, vai tuottaako ajatus laajemmasta julkisessa tilassa toimivasta kuulijakunnasta sittenkin selvempää julkista keskustelua. Entä mikä on yksittäisiksi jäävien puheenvuorojen rooli? Vastaus ei ole yksiselitteinen.

Riittävätkö jostakin asiasta esitetyt erilaiset kannat keskusteluksi? Yleensä keskustelulta on ollut tapana edellyttää enemmän - vähintäänkin, että kantoja ilmaisevat puheenvuorot reagoivat toisiinsa. Muun muassa keskustelunanalyytikot näyttävät edellyttävän keskusteluksi kutsuttavalta prosessilta tällaista vuorovaikutuksellisuutta [...]. Sikäli kuin keskustelu ymmärretään tähän tapaan vuoropuheluksi, dialogiksi, ei toisiinsa reagoimattomista monologisista puheenvuoroista rakennu keskustelua, vaikka niissä tuotaisiinkin julki mielipiteitä samasta asiasta. (Pietilä 2010 [2002]b, 449)

Pietilän pohdinta haastaa analyysissa esitetyn ajatuksen siitä, että artikuloidut kannat samasta aiheesta asettuvat vuoropuheluun, vaikka kommentit eivät tätä eksplisiittisesti teekään. Pietilä jatkaa.

Voidaan kuitenkin väittää, että vaikka julkiseksi keskusteluksi kutsuttu prosessi koostuisi kokonaisuudessaan mainitunlaisista monologeista, se silti on vastavuoroista, joskin toisessa mielessä kuin dialogimallia noudattava henkilökohtainen keskustelu. (Emt.)

Onkin syytä palauttaa mieleen vähimmäisoletus siitä, että julkisossa sen jäsenet "pyrkivät tai osallistuvat julkiseen vuorovaikutukseen" (Pietilä 2010 [2006], 260). Julkison toiminnallisessa positiossa olennaista ei siis ole niinkään keskustelun virittyminen, vaan se, että siihen pyritään. Jos yksittäiset monologisiksi jäävät puheen- 
vuorot analyysin perusteella pyrkivät keskusteluun, voitaneen todeta, että niissä ylitetään rajaa kohti julkisoutta. Pohdittavaksi kuitenkin jää, kuinka ratkaisevassa roolissa keskustelun todelliset ja potentiaaliset osapuolet ovat. Keskustelunanalyyttisesta perspektiivistä näyttää siltä, että puhuttelemalla pääasiallisesti "muita" (analyysin 1. vaihe) ja muita (analyysin 2. vaihe) paikallisen ja maakunnallisen verkkolehden kommentoijat asettuvat aktuaalisen dialogin sijaan laajempaan "julkiseen vuorovaikutukseen". Keskusteluun haastetaan myös uusia, aiheen kannalta tärkeiksi koettuja toimijoita (ks. Taulukko 1.), ja kommentointi tulee jopa kirjaimellisesti tulkituksi julkisen keskustelun areenana.

KS, Tuntematon, 15.11.2012, 19:54

Nämä kommenttipalstat ovat mielestäni mitä parhain demokratian jatke. Vihdoinkin me tälläiset tavan pulliaisetkin saamme mielipiteillemme edes jonkinlaista levikkiä. Nimettömänähän täällä kirjoitellaan, mutta harva meistä nimeään äänestyslippuunsakaan on laittanut.

Samaan hengenvetoon on toki todettava, etteivät SL:n tai KS:n kommentoijat toteuta "pyrkimystä" julkisesta keskustelusta kovinkaan selväsanaisesti tai tietoisesti. Kyse on ennen kaikkea kommenttien positiosta keskustelullisessa kokonaisuudessa, ja tästä näkökulmasta HS:n kommentointikulttuuri näyttäytyy kenties ristiriitaisempana. Vaikka keskenään väittelevät nimimerkit toteuttavat keskustelun dialogista vaatimusta (Taulukko 3.), tarkempi tarkastelu osoittaa, että monet tutkituista kommenttiketjuista typistyvät kahden tai muutaman kommentoijan vuoropuheluiksi varsin spesifeistä aiheista. Mahdollistaako tällainen pidempi vuoropuhelu todellisen näkemysten välienselvittelyn siinä julkisessa vuorovaikutuksen kehyksessä, jossa julkison on määrä toimia, vai palautuuko keskustelu sittenkin takaisin henkilökohtaiselle tasolle, kun muut jättäytyvät väittelyn ulkopuolelle? Ja edelleen, mistä henkilökohtaiselle tasolle palautuva dialogi viestii?

Vastausta kysymykseen voi etsiä muun muassa jaetusta ongelmasta, sillä uutisaihe itsessään asettaa kommenttiketjuissa käydyt keskustelut erilaisiin konteksteihin. Paikallisessa ja maakunnallisessa viitekehyksessä keskustelujen taustalla vaikuttavat vahvat kysymyksenasettelut kaivoksen edesottamuksista ja esimerkiksi taloudellisesta merkityksestä. "Julkisona verkossa vääntävät yhteisöt tai leirit eivät ole suoranaisesti keskustelun tuotetta. Keskustelu vain tuo julki asetelman, joka on vallinnut jo etukäteen sen ulkopuolella tai ainakin mahdollisuutena" (Pietilä 2010 [2001], 415). Valtakunnallisessa kontekstissa tällaista asetelmaa suhteessa kaivokseen ei kenties synny, ja voidaankin kysyä, onko Talvivaara HS:n kommentoijille sittenkään riittävän yhteinen ongelma? Pelkän keskustelunanalyysin perusteella tähän on mahdotonta vastata. Ketjujen analyysi jättää kuitenkin vaikutelman siitä, että kommenteissa esille nousevat vaihtoehtoiset aiheet, kuten kaivosteollisuuden turvallisuus ja merkitys, synnyttävät HS:n kontekstissa laajempaa, usean kommentoijan keskustelua.

On joka tapauksessa selvää, että kommenttiketjuissa syntyy julkisolle elimellistä näkemysten vastakkainasettelua, käytiin keskustelua sitten aiheesta tai sen vierestä. 
Tästä huolimatta kommenttiketjujen erimielisyyttä ei voi sellaisenaan tulkita viitteeksi julkisosta, sillä internet näyttäytyy kokonaisuudessaan varsin negatiivisena ympäristönä: käyttäjillä on tapana tuoda esille verkkoympäristössä lähinnä erimielisyyttään (Pietilä 2010 [2001], 409; Pietilä 2010 [2002]a; Savolainen 1999). Toisaalta Ridellin $(2000,58)$ mukaan niin sanotulla reilulla eripuralla on oma paikkansa kaikissa julkisissa keskusteluissa: "erimielisyys ei ole julkisuuden aihe vaan keino setviä ongelmallisia ja kiistanalaisia kysymyksiä julkisesti" (ks. myös Arpo 2005, 293). Ymmärrys erimielisyydestä julkison elinehtona onkin monella tapaa mielenkiintoinen. Keskustelunanalyysi nimittäin olettaa, että erimielisten eli preferoimattomien vuorojen "tuottamiseen liittyvissä käytänteissä on jotakin enemmän" (Tainio 1997, 95), vaikka perinteisessä keskustelussa suotavampaa on samanmielisyys (ks. esim. Heritage 1996, 265; Tainio 1997). Kenties erimielisyyden tekee kommenttiketjuissa ongelmalliseksi se, ettei sen ilmaisemiseen kytkeydy kasvokkaiselle keskustelulle tyypillisiä viitteitä pyrkimyksestä "konfliktien välttämiseen ja sujuvaan yhteistyöhön" (emt, 102; ks. myös 104), mikä tulee edelleen tulkituksi muun muassa leimahteluna (flaming) ja provokaationa (vrt. esim. Pietilä 2010 [2002]a, 426; Bird 2011, 498-500). Tutkituissa kommenttiketjuissa tällaisia piirteitä esiintyy kuitenkin suhteellisen vähän. Erimielisyys ilmenee pitkälti vastakkaisina - useimmiten perusteltuina - kantoina. Myös samanmielisyys näyttäytyy eri tavoin kuin kasvokkaisessa keskustelussa. Kyse ei ole yksinomaan suotavasta käytöksestä tai sosiaalisesta solidaarisuudesta, vaan kantojen tukemisesta ja vahvistamisesta. Prefenssijäsennysten kommenteissa saamia muotoja voikin syystä pitää julkison toiminnan kannalta merkityksellisinä - "jonakin enempänä".

KS, Tuntematon, 5.11.2012, 08:12

"hih hih"

Oikeastiko tämä asia jotakuta naurattaa? Olen samaa mieltä 22.02 kirjoittajan kanssa.

Toiminta on vastenmielistä. Pörssiyhtiöt voivat tehdä mitä huvittaa. Viranomaisten val-

vonta ja kurinpito on näennäistä, isojen poikien bisneksiin ei ole lupa sekaantua.

Kokonaisuudessaan menetelmällinen testaus antaa viitteitä siitä, että verkkouutisten kommentointi pitää sisällään julkisoiden ituja. Kommenteissa keskustelevan julkison kehitykselle on elintärkeää, että uutisaiheen kautta kommentoijat kytkeytyvät oikeanlaiseen ongelmaan tai kysymykseen: "asioista tulee julkisia sanan tärkeimmässä merkityksessä silloin, kun ne näyttävät yhteisiltä ongelmilta ja saavat ihmiset puhumaan" (Heikkilä \& Kunelius 1997, 5). Kommentoivan julkison määrittelyssä huomio kiinnittyykin toiminnallisiin motiiveihin. Se, että verkko ympäristönä mahdollistaa sosiaalisista paineista vapaamman vuoropuhelun, ei näyttäydy julkisen keskustelun kannalta sittenkään yksinomaan esteenä - käytöstapojen sijaan päärooliin pääsevät kannat ja halu esittää niitä julkisesti. 


\section{Viitteet}

1 Artikkeli on osa väitöskirjatutkimusta. Kiitän työn tukemisesta Emil Aaltosen Säätiötä.

2 Lincoln Dahlberg $(2001,616)$ on kuvannut kolme tieteellisen keskustelun retorista ja käytännöllistä leiriä, jotka viittaavat internetin mahdollisuuksiin julkisessa keskustelussa: "First, a communitarian camp, which stresses the possibility of the Internet enhancing communal spirit and values. Second, a liberal individualist camp, which sees the Internet as assisting the expression of individual interests. Third, a deliberative camp, which promotes the Internet as the means for an expansion of the public sphere of rational-critical citizen discourse - discourse autonomous from state and corporate power through which public opinion may be formed that can hold official decision makers accountable."

3 Diskursiivisen perinteen edustajina ja luojina pidetään yleisesti muun muassa Herbert Blumeria sekä Robert Parkia ja Gabriel Tardea (Ridell, 2010). Tähän ryhmään kuuluvat myös suomalaiset uranuurtajat Veikko Pietilä ja Seija Ridell, jotka ovat luoneet ja tuoneet julkiso-termin suomalaiseen tutkimusperinteeseen yleisön käsitteen rinnalle (Pietilä \& Ridell 1998).

4 Habermasille julkisen keskustelun ideaali muodostuu 1800-luvun porvarillisesta julkisesta tilassa, jossa kansalaiset ja lehdistö osallistuivat yhdessä ja tasavertaisena rationaaliseen ja kriittiseen vuoropuheluun yhteiskunnallisesti merkittävistä kysymyksistä. Tätä ideaalia täydentää edelleen deliberatiivisen (julkisen harkinnan) demokratian ihanne, joka korostaa kansalaisten mahdollisuutta osallistua näihin merkityksellisistä asioista käytäviin keskusteluihin (esim. Dryzek 2000,1; Habermas 2004 [1962]).

5 Kommentoinnin ilmeisimpänä rakenteellisena ehtona voitaneen pitää verkkolehden kommentointimahdollisuutta ja edelleen esimerkiksi käyttäjän internetyhteyttä.

6 Aineisto on kerätty kunkin verkkolehden arkistosta hakusanaa Talvivaara* käyttäen. Sittemmin sekä Sotkamo-lehden että Kainuun Sanomien verkkoarkistoa on typistetty, eikä hakusana tuota yhtä laajaa tulosta.

7 Sotkamo-lehden verkkouutisissa on ollut kommentointimahdollisuus vuodesta 2006 lähtien ja ennakkomoderointi vuodesta 2012 lähtien. Kainuun Sanomissa jälkimoderointi muutettiin ennakkomoderoinniksi vuonna 2012. Kommentointimahdollisuus verkkolehteen tuli arviolta vuonna 2009. Helsingin Sanomissa kommentointimahdollisuus on ollut noin kymmenen vuotta, ja käytössä on ollut alusta asti ennakkomoderointi. Tiedot ovat peräisin sähköpostikeskusteluista lehtien edustajien kanssa vuonna 2014.

8 Esimerkiksi Veikko Pietilän (2010 [2002]a) verkkokeskusteluareenojen keskustelunanalyysissa neljältä areenalta on kertynyt yhteensä 903 puheenvuoroa, eli hieman yli 225 puheenvuoroa areenaa kohti.

9 Hakulinen on poiminut lyhennettynä seuraavan ehtojen luettelon: 1. Puhuja vaihtuu toistamiseen tai ainakin vaihdoksia tapahtuu. 2. Useimmiten on niin, että yksi puhuu kerrallaan. 3. Päällekkäisyydet ovat yleisiä mutta kestävät lyhyeen. 4. On yleistä, että siirtymä vuorosta toiseen tapahtuu sujuvasti: ilman katkosta ja ilman pitkällistä päällekkäisyyttä. 5. Vuorojen järjestys sen enempää kuin niiden pituuskaan ei ole kiinteä, vaan vaihtelee. 6 . Keskustelun pituutta ei ole yleensä määrätty ennalta. 7. Vuorojen sisältöä ei liioin ole ennalta määrätty. 8. Vuorojen suhteellista jakautumista puhujien kesken ei ole ennalta määrätty. 9. Puhe voi olla jatkuvaa tai katkeilla. 10. Vuoroja jaetaan jonkinlaisten annostelutekniikoiden avulla. 11. Erilaisia vuorojen rakenneyksiköitä on käytössä keskustelun eri kohdissa. 12. Häiriöitä tai rikkeitä, joita vuoronvaihdossa sattuu, voidaan keskustelun kuluessa oikaista. (Hakulinen 1997b, 35)

10 Moderointi on mahdollista tulkita kommentteja ohjaavaksi käytännöksi, mutta se ei itsessään ohjaa sisältöä, vaan määrittelee tietyt laadulliset raamit keskustelulle.

11 Marja-Leena Sorjosen $(1997,111)$ mukaan "[k]orjausjäsennys on keskustelunanalyysissa käytetty kattotermi käytänteille, joiden avulla keskustelijat käsittelevät puhumisessa, puheen kuulemisessa ja ymmärtämisessä esiintyviä ongelmia."

12 Kommentointiketjujen vuorottelujäsennystä olisi mahdollista tutkia myös kommentointiajankohtia tarkastelemalla, jolloin aineistosta selvitettäisiin muun muassa sitä, millaisella frekvenssillä kommentteja tuotetaan ja missä vaiheessa kommentointi-into hiipuu. Keskustelullisten elementtien kannalta tällaisen analyysin anti ei kuitenkaan vaikuta kovinkaan hedelmälliseltä.

13 Toisaalta uutinen voi pitää sisällään jälkijäseniä, joissa viitataan esimerkiksi muiden lähteiden kantoihin tai aikaisempiin uutisiin. Näiden jälkijäsenten merkitys kommentoinnille on tässä artikkelissa analysoidun aineiston osalta kuitenkin varsin pieni. 
14 HS:n kommenttiketjussa on mahdollista vastata suoraan tiettyyn kommenttiin. Tällöin uuden kommentin alkuun tulevat näkyviin ensimmäiset rivit kommentin kohteesta ja jatkolinkki "näytä lisää".

15 HS:n aineiston nimimerkit on muutettu. Osa kommentoijista käyttää nimeen viittaavaa nimimerkkiä, jonka perusteella kommentoija on mahdollista tunnistaa.

16 Perinteisessä keskustelunanalyysissa vierusparit jo nimensäkin perusteella kuvaavat vierekkäisiä keskustelun osasia (esim. Raevaara 1997; Heritage 1996). Tässä tutkimuksessa vieruspareiksi on kuitenkin tulkittu kaikki tavalla tai toisella etujäsenen tai jälkijäsenen rooliin asettuvat kommentit. Myös uutisessa esitetyt kannanotot on tulkittu etujäseniksi, jotka voivat tuottaa jälkijäseniä (ks. esim. Liite 1.).

17 Kysymyksenasettelussa huomionarvoista on ymmärrys siitä, että tietylle taholle (uutinen tai kommentti) kohdistuva kommentti ei automaattisesti ole jälkijäsen eikä edelleen eri- tai samanmielinen. Esimerkiksi uutislähteelle esitetty suora kysymys edustaa etujäsentä.

\section{Kirjallisuus}

Arpo, Robert (2005). Internetin keskustelukulttuurit. Tutkimus internet-keskusteluryhmien viesteissä rakentuvista puhetavoista, tulkinnoista ja tulkinnan kehyksistä kommunikaatioyhteiskunnassa. Joensuu: Joensuun yliopisto.

Bird, Elizabeth (2011). Seeking the audience for news: Response, news talk, and everyday practices. Teoksessa: The Handbook of Media Audiences. New York: Blackwell Publishing Ltd, 489-508

Blumer, Herbert (2010 [1946]). Joukko, massa ja julkiso. Teoksessa: Veikko Pietilä ja julkisuuspiiri. Julkisot, yleisöt ja media. Suomennoksia ja kirjoituksia julkisista vuorovaikutus- ja toimintamuodoista. Tampere: Tampere University Press, 113-132.

Coleman, Stephen \& Gøtze, John (2001). Bowling Together: Online Public Engagement in Policy Deliberation. Internetlähde: http://www.acteurspublics.com/files/epublic/pdf/scoleman-jgotze-bowling-together.pdf

Coleman, Stephen \& Ross, Karen (2010). The Media and the Public. "Them" and "Us" in Media Discourse. Chichester: Wiley-Blackwell.

González-Lloret, Marta (2011). Conversation analysis of computer-mediated communication. CALICO Journal 28(2), 308-325.

Dahlberg, Lincoln (2001). The Internet and democratic discourse: Exploring the prospects of online deliberative forums extending the public sphere. Information, Communication Q Society 4:4 2001, 615633.

Domingo, David; Quandt, Thorsten; Heinonen, Ari; Paulussen, Steve; Singer, Jane B. \& Vujnovic, Marina (2008). Participatory journalism practices in the media and beyond. An international comparative study of initiatives in online newspapers. Journalism Practice, Vol. 2, No 3, 2008, 326-342.

Dryzek, John (2000). Deliberative Democracy and Beyond. Liberals, Critics, Contestations. Oxford: Oxford University Press.

Habermas, Jürgen (2004 [1962]). Julkisuuden rakennemuutos. Tutkimus yhdestä kansalaisyhteiskunnan kategoriasta. Suom. Veikko Pietilä. Tampere: Vastapaino.

Hakulinen, Auli (1997a). Johdanto. Teoksessa: Keskustelunanalyysin perusteet. Tampere: Vastapaino, 13-17.

Hakulinen, Auli (1997b). Vuorottelujäsennys. Teoksessa: Keskustelunanalyysin perusteet. Tampere: Vastapaino, 32-55.

Harju, Auli (2001). Varaventtiili vai voimavara? Viranhaltijoiden ja luottamushenkilöiden näkemyksiä paikallisesta julkisesta keskustelusta. Tampereen yliopisto. Tiedotusopin laitos. Pro gradu -tutkielma.

Heikkilä, Heikki \& Kunelius, Risto (1997). Julkisen journalismin äärellä. Tiedotustutkimus 4/1997, 4-21.

Heikkilä, Heikki; Ahva, Laura; Siljamäki, Jaana \& Valtonen, Sanna (2012). Kelluva kiinnostavuus. Tampere: Vastapaino.

Heinonen, Ari (2008). Yleisön sanansijat sanomalehdissä. Tampereen yliopiston tiedotusopin laitoksen julkaisuja A108.

Heritage, John (1996). Harold Garfinkel ja etnometodologia. Suomentajat: Ilkka Arminen ym. Helsinki: Gaudeamus.

Herkman, Juha \& Vainikka, Eliisa (2012a). Uudet lukemisyhteisöt, uudet lukutavat. Tampereen yliopiston Journalismin, viestinnän ja median tutkimuskeskuksen (COMET) tutkimushanke.

Herkman, Juha \& Vainikka, Eliisa (2012b). Lukemisen tavat. Tampere: Tampere University Press. 
Hermida, Alfred \& Thurman, Neil (2008). A clash of cultures: The integration of user-generated content within professional journalistic frameworks at British newspaper websites. Journalism Practice, 2(3), 343-356.

Hujanen, Jaana (2000). Journalismin maakunnallisuus. Alueellisuuden rakentuminen maakuntalehtien teksteissä ja tekijöiden puheessa. Jyväskylän yliopisto: Jyväskylä studies in communication 11.

Londen, Anne-Marie (1997). Kahden- ja monenkeskinen keskustelu. Teoksessa: Keskustelunanalyysin perusteet. Tampere: Vastapaino, 56-74.

Matikainen, Janne (2010). Verkkotutkimuksen metodologisia näkökulmia. Internetlähde: http://blogs. helsinki.fi/jmatikai/files/2010/og/Verkkometodjm.pdf

Nikunen, Kaarina (2011). Enemmän vähemmällä. Talouslaman ja teknologisen murroksen vaikutukset suomalaisissa toimituksissa 2009-2010. Tampereen yliopisto: CMT.

Ojajärvi, Sanna \& Valtonen, Sanna (2011). Karhun ja kassakoneen naapurissa: journalismin ja kansalaisten venäjät. Teoksessa: Näin naapurista. Venäjän ja kansalaisten media-kuvat. Tampere: Vastapaino, 19-67.

Papacharissi, Zizi (2002). The virtual sphere: The internet as a public sphere. New Media Society 2002 4:9, 9-27.

Pietilä, Veikko (2010 [1999]). Julkiso ja yleisö. Teoksessa: Veikko Pietilä ja julkisuuspiiri. Julkisot, yleisöt ja media. Suomennoksia ja kirjoituksia julkisista vuorovaikutus- ja toimintamuodoista. Tampere: Tampere University Press, 201-216.

Pietilä, Veikko (2010 [2001]). Yleisönosasto ja internet keskusteluareenoina. Teoksessa: Veikko Pietilä ja julkisuuspiiri. Julkisot, yleisöt ja media. Suomennoksia ja kirjoituksia julkisista vuorovaikutus- ja toimintamuodoista. Tampere: Tampere University Press, 397-422.

Pietilä, Veikko (2010 [2002]a). Verkkokeskusteluareenat - Deliberatiivista julkisuuttako? Teoksessa: Veikko Pietilä ja julkisuuspiiri. Julkisot, yleisöt ja media. Suomennoksia ja kirjoituksia julkisista vuorovaikutusja toimintamuodoista. Tampere: Tampere University Press, 423-446.

Pietilä, Veikko (2010 [2002]b). Siltasotaa Tampereella - Julkinen keskustelu Koskenniskan siltahankkeesta. Teoksessa: Veikko Pietilä ja julkisuuspiiri. Julkisot, yleisöt ja media. Suomennoksia ja kirjoituksia julkisista vuorovaikutus- ja toimintamuodoista. Tampere: Tampere University Press, 447-475.

Pietilä, Veikko (2010 [2006]). "Matti Matalaisen" julkea ehdotus ja vähän muutakin. Teoksessa: Veikko Pietilä ja julkisuuspiiri. Julkisot, yleisöt ja media. Suomennoksia ja kirjoituksia julkisista vuorovaikutusja toimintamuodoista. Tampere: Tampere University Press, 243-267.

Pietilä, Veikko \& Ridell, Seija (1998). Julkea ehdotus. Tiedotustutkimus 1/1998: 95.

Pietilä, Veikko \& Ridell, Seija (2010). Yleisö käsitystapojen ristiaallokossa. Teoksessa: Veikko Pietilä ja julkisuuspiiri. Julkisot, yleisöt ja media. Suomennoksia ja kirjoituksia julkisista vuorovaikutus- ja toimintamuodoista. Tampere: Tampere University Press, 295-320.

Pöyhtäri, Reeta; Haara, Paula \& Raittila, Pentti (2013). Vihapuhe sananvapautta kaventamassa. Tampere: Tampere University Press.

Raevaara, Liisa (1997). Vierusparit - esimerkkinä kysymys ja vastaus. Teoksessa: Keskustelunanalyysin perusteet. Tampere: Vastapaino, 75-92.

Reagle, Joseph M. Jr (2015) Reading the Comments. Likers, Haters and Manipulators at the Bottom of the Web. Cambridge/London: The MIT Press.

Ridell, Seija (2000). Kansalaisjulkisuuden kokeilua verkossa - Mansefoorumi ja paikallisen julkisen viestinnän käytännöt. Teoksessa: Verkkotorilla: Internet kansalaisviestinnän ja paikallisen julkisuuden tilana. Paikallisuus verkkomediassa -julkaisun loppuraportti.

Ridell, Seija (2006). Yleisö. Teoksessa: Seija Ridell; Pasi Väliaho \& Tanja Sihvonen (toim.). Mediaa käsittämässä. Tampere: Vastapaino, 233-257.

Ridell, Seija (2010). Johdannoksi teokseen. Teoksessa: Veikko Pietilä ja julkisuuspiiri. Julkisot, yleisöt ja media. Suomennoksia ja kirjoituksia julkisista vuorovaikutus- ja toimintamuodoista. Tampere: Tampere University Press, 7-31.

Savolainen, Reijo (1996). Suurajot vai surmanajot? Tiedotustutkimus 4/1996, 48-65.

Sorjonen, Marja-Leena (1997) Korjausjäsennys. Teoksessa: Keskustelunanalyysin perusteet. Tampere: Vastapaino, 111-137.

Stromer-Galley, Jennifer (2003). Diversity of political conversation on the Internet: Users' perspectives. Journal of Computer-Mediated Communication. Volume 8, Issue 3.

Tainio, Liisa (1997). Preferenssijäsennys. Teoksessa: Keskustelunanalyysin perusteet. Tampere: Vastapaino, 93-110. 
Liitteet

Liite 1. Sotkamo-lehden kommentoiduin uutinen tekstinä.

SL: 4.2.2013

\section{Antti Lankinen kirjoitti ministerille: "Talvivaarassa nerokkaita vain rahoitusratkaisut"}

Sotkamon seurakunnan kappalainen Antti Lankinen on myös lähestynyt Sotkamossa viime perjantaina vieraillutta kehitysministeri Heidi Hautalaa.

Heidi Hautalan lisäksi poliittiselle sihteerille Sallamaarit Muhoselle osoitetussa kirjeessä Kainuun luonnosuojelupiirin kaivosvastaava Antti Lankinen kertoo olevansa yksi niistä henkilöistä, jotka toivovat Talvivaaran toiminnan päättymistä. Kättään hän ei ministerin kysyessä mielipidettä nostanut, koska ei omien sanojensa mukaan pidä kyllä tai ei-kysymyksistä.

- Olen ollut kriittinen ja epäileväinen Talvivaaran toiminnan suhteen jo vuodesta 2007 lähtien. Marraskuussa sanoin YLE:n haastattelussa Talvivaaran avaavan helvetin portit.

Lankisen mielestä nikkelin louhiminen Talvivaarassa käytettävillä menetelmillä ei ole kannattavaa eikä ekologisesti kestävää.

- Talvivaaran kaivoksella nerokkaita ovat vain rahoitusratkaisut. Rahan hankkimisessa siellä on onnistuttu, samaa osaamista ei ole löytynyt ympäristöongelmien ratkaisemiseen.

Antti Lankinen sanoo kirjeessään ministerille nyt Talvivaaran ylittäneen sen kriittisen pisteen, jossa koko kaivoksen aluetaloudellinen vaikutus on kääntynyt negatiiviseksi.

- Miksi raskaasti tappiollista toimintaa pitäisi vielä tukea 100-200 miljoonan euron lisäpanostuksella.

Lue perjantain 8.2. Sotkamo-lehdestä, mihin Antti Lankinen ohjaisi valtion sijoitusyhtiön rahat Talvivaaran tukemisen sijaan.

KUVATEKSTI: Antti Lankinen kirjoitti ministeri Heidi Hautalalle näkemyksiään Talvivaaran kaivoksen tilanteesta.

\section{Liite 2. Kainuun Sanomien kommentoiduin uutinen tekstinä.}

\section{Jätevesivuoto 5000-6000 kuutiota tunnissa}

Talvivaaran uraanipitoista vettä on kulkeutunut kilometrien päähän vuotokohdasta kaivosalueen vesistöihin, kertoo Säteilyturvakeskus. Tiistaina ja keskiviikkona kaivosalueelta kerättyjen vesinäytteiden uraanipitoisuudet olivat nousseet yli 50-kertaisiksi alueella aiemmin mitattuun uraanipitoisuuteen verrattuna. Talvivaaran kaivoksen jätevesivuodoksi arvioidaan nyt 5 ০oo-6 ooo kuutiota tunnissa. Suurin osa jätevedestä jää kaivoksen alueelle, mutta osa vuotaa edelleen kohti Salmista. Vuoto havaittiin sunnuntaiaamuna, mutta se on voinut alkaa jo lauantaiiltana. Kaikkiaan puhdistamatonta vettä on siis voinut vuotaa kipsisakka-altaasta jo yli 200000 kuutiota.

Kipsisakka-altaan vuotokohtaa tai -kohtia ei ole vieläkään saatu varmistetuksi.

Talvivaaran kaivokselta vuotava jätevesi on levinnyt jo ympäristöön. Jätevesialtaan vettä on päässyt alueelta läheiseen ojaan, jota pitkin jätevesi on kulkenut kohti Salmista ja Kalliojärveä.

- Kipsisakka-altaan pohjoispuolen suo-ojassa on virrannut altaan vettä. Ikävä kyllä se oli ehtinyt jo joidenkin tuntien ajan vuotaa sinne, ennen kuin asia huomattiin, arvioi viestintäpäällikkö OlliPekka Nissinen.

Nissisen mukaan pääosa sulfaatti ja metallipitoisesta jätevedestä valuu yhä etelän varoaltaille. Uutta tilannetta yritetään korjata suurtehopumpun ja maapadon avulla. Nyt kahteen suuntaan liikkuva jätevesi vuotaa todennäköisesti samasta kohdasta.

- Tämä (pohjoisvuoto) menee vedenjakajan ja maaston muotojen takia toiseen suuntaan, Nissinen kertoo.

Pohjoispuolellakin on jälkikäsittelyallas, mutta jätevesi virtaa sen ohi. Vuotokohtaa etsitään yhä. Kun se löytyy, allas pyritään tilkitsemään sen sisäpuolelta.

Jormaskylä-Korholanmäen osakaskunnan puheenjohtaja Leo Schroderus tutustui sunnuntaina illalla seitsemän jälkeen tilanteeseen. Schroderus sanoi Kainuun Sanomille, että ruman ruosteenruskeaa vettä tulee kaivosalueelta tuutin täydeltä Salmiseen, Kalliojärveen, Kolmisoppeen ja edelleen Jormasjärveen. 
- Tuommoinen 80 sentin halkaisijaltaan oleva rumpu työntää vettä liki ylälaitaa myöten, Schroderus sanoi ja arvioi, että vettä on ilmeisesti yritetty neutralisoida, sillä tieltä on kipattu ojaan kalkkia.

Schroderus kertoi kertoneensa havainnostaan myös viestintäpäällikkö Nissiselle, joka oli hänen mukaansa vielä viiden aikaan todennut, ettei vettä vuotaisi Oulujärven vesistöön vaan ainoastaan Savon suuntaan.

Schroderus kertoo pelänneensä vastaavaa onnettomuutta jo pitkään, sillä altaat on eristetty vain 1,5 $\mathrm{mm}: \mathrm{n}$ muovilla.

- Sanoin jo alun alkaen, että on vain ajan kysymys, koska muovi pettää. Ja jos se yhdestä kohti on pettänyt, se pettää kohta joka paikasta.

Kipsisakka-altaasta löydettiin sunnuntaiaamuna kello seitsemän jälkeen kaksi vuotokohtaa. Vuotojen vuoksi metallitehtaan tuotanto on pysäytetty.

Patovalli ei ole murtunut ja altaan patopenkereet ovat ehjät. Sen sijaan kipsisakka-altaan vettä suotautuu läpi patovallista allasalueen itälaidalla. Kipsisakka-altaan vesi ja pohjasakka sisältävät kaivoksen puhdistettuja poistovesiä suuremman määrän metalleja ja sulfaatteja.

Vuotomäärästä ei toistaiseksi ole tietoa. Paikalla käynyt ylitarkastaja Unto Ritvanen Kainuun elykeskuksesta sanoi iltapäivällä, että ympäristövaikutuksia oli liian aikaista arvioida.

- Vuotomäärä voi olla parisataa litraa sekunnissa. Vuoto vaikuttaisi pienemmältä kuin edellisellä kerralla 2010, Ritvanen arvioi.

Hän pitää mahdollisena, että vuodon on aiheuttanut altaan pohjalla olevan suojamuovirakenteen ratkeaminen.

- Vettä pääsee karkuun parista paikasta penkereen alitse. Vuotokohdan voi ensi hätään peittää esimerkiksi tiivistysmatoilla, Ritvanen kertoo.

Yhtiö seuraa vuotovirtauksen etenemistä tunnin välein.

- Aamulla huomattu päävuotokohta on parin kolmen metrin alueella. Vettä tulee puronomaisesti, sanoi yhtiön viestintäpäällikkö Olli-Pekka Nissinen.

- Vuotava vesi kerääntyy turva-altaisiin, joiden riittävyyttä varmistetaan, Nissinen täsmensi. Hänen mukaansa turva-altaissa on kuitenkin runsaasti tilaa.

Myös Ritvasen mukaan vuoto näyttäisi pysyvän kaivosalueella.

- Alueella on käytössä vielä paljon varastointitilaa jälkikäsittely-yksiköissä.

Vuodon alkuperää ja laajuutta tutkittiin yhä illalla. Välittömät turvaamis- ja eristämistyöt paikalla ovat käynnissä. Kipsisakka-altaan alapuolisilla alueilla on turvapadot ja niillä ehkäistään kipsisakkaaltaan veden ja sakan pääsyä eteenpäin kaivosalueelta. Kaivosalueella työskenteli pitkin päivää useita kaivinkoneurakoitsijoita, jotka vahvistivat turva-altaiden rakenteita.

- Töihin ryhdyttiin heti asian paljastuttua, kertoo yhtiön metallituotannon johtaja Mikko Korteniemi.

Hänen mukaansa töitä tehdään vuorokauden ympäri niin kauan, että tilanne on varmuudella hallinnassa.

Viranomaisten tiedossa ei sunnuntaina ollut, että kipsisakka-altaan vesiä olisi päässyt kaivosalueen ulkopuoliseen vesistöön.

Myös yhtiöstä arvioitiin illalla, että metalleja ja sulfaatteja sisältävä vesi saadaan pysymään kaivosalueella.

- Talvivaara tekee kaiken voitavansa vuodon korjaamiseksi mahdollisimman nopeasti sekä ympäristövaikutusten minimoimiseksi. Tilanteesta on ilmoitettu viranomaisille, sanoo Talvivaara tiedotteessaan.

Talvivaaran mukaan kipsisakka-allas on vuotanut myös vuosina 2008 ja 2010.

KUVATEKSTI: Metallituotannon johtaja Mikko Korteniemi vastaili toimittajien kysymyksiin maanantaina iltapäivällä. 


\section{Liite 3. Helsingin Sanomien kommentoiduin uutinen tekstinä.}

\section{Talvivaaran uraanipitoista vettä kulkeutunut kilometrien päähän}

Talvivaaran uraanipitoista vettä on kulkeutunut kilometrien päähän vuotokohdasta kaivosalueen vesistöihin, kertoo Säteilyturvakeskus. Tiistaina ja keskiviikkona kaivosalueelta kerättyjen vesinäytteiden uraanipitoisuudet olivat nousseet yli 50-kertaisiksi alueella aiemmin mitattuun uraanipitoisuuteen verrattuna.

Ympäristökeskuksen mukaan Talvivaaran jätevesivuodon haitat kaivosalueen ulkopuolella ovat kuitenkin vielä vähäisiä. Suurimmat haitat liittyvät raskasmetalleihin, joiden pitoisuuksista saadaan tietoa ensi viikon alussa. Terveyshaittaa vuodosta ei Säteilyturvakeskuksen mukaan ole koitunut.

Talvivaaran kaivoksen kipsisakka-altaan todettiin jälleen perjantaina vuotavan. Suppilomainen reikä saatiin tukittua yöllä hiekkasäkkien ja bentoniittimaton suikaleiden avulla, mutta se alkoi vuotaa uudelleen aamupäivällä. Sulfaattia ja raskasmetalleja sisältävä vesi valuu maapohjaisiin varoaltaisiin.

"Vuoto on aiempia päiviä pienempi, mutta sitä yritetään tukkia kivituhkan ja bentoniitin avulla. Olemme saaneet avuksi puolustusvoimilta ja palolaitokselta lisää matalapohjaisia veneitä, jotka helpottavat altaalla liikkumista", kertoo Talvivaaran viestintäpäällikkö Olli-Pekka Nissinen.

Vuotokohta sijaitsee noin 15 hehtaarin laajuisen allaslohkon keskivaiheilla. Reikä on usean metrin paksuisessa kipsisakassa, jonka päällä on 1,5 metriä vettä.

"Suppilomainen reiän halkaisija on sakan yläosassa noin kymmenen metriä. Reikä kapenee jyrkästi alaspäin mentäessä", Nissinen sanoo.

Lähipäivät ovat eteläpuolella sijaitsevan Vuoksen vesistön kannalta kriittiset, sillä kaivosalue on täyttymässä. Yhtiö joutui jo torstaina juoksuttamaan alimmista varoaltaista vettä Lumijokeen, josta vesi purkautuu Vuoksen suuntaan. Tämä vesi on yhtiön mukaan pitoisuuksiltaan ympäristöluvan mukaista.

Nissinen ei osannut vielä aamulla sanoa, onko turvapadoista juoksutettu vettä yön aikana Vuoksen valuma-alueelle Lumijokeen. Eilen turvapadoista juoksutettiin vettä viitisen tuntia. Vesi oli Nissisen mukaan pitoisuuksiltaan ympäristöluvan mukaista poistovettä.

Eteläisen turvapadon on tarkoitus valmistua tänään.

Ely-keskuksen mukaan jätevettä ei olisi saanut varastoida kipsisakka-altaaseen. Nissisen mukaan varastoinnin taustalla on ennätyssateinen viime kesä ja viime kevään runsaat sulamisvedet, jotka ovat tuoneet kaivosalueelle vettä. Talvivaaran vuotuinen puhdistettujen vesien päästökiintiö tulee täyteen marras-joulukuun vaihteessa.

"Näitä on varastoitu eri altaisiin sitten", Nissinen sanoo.

Suomen ympäristökeskuksen arvion mukaan vuodossa on päässyt luontoon turvapadon ohi 20 o०o kuutiota jätevettä.

KUVATEKSTI: Betoniittimattoja ja hiekkasäkkejä kipsisakka-altaan reunavallilla Talvivaarassa torstaina. 
Liite 4. Kymmenen kommentoiduinta uutista

\begin{tabular}{|c|c|c|c|}
\hline \multirow[t]{11}{*}{ HS } & Päivämäärä & Kommentit & Otsikko \\
\hline & 5.11 & 68 & Talvivaaran vuoto näkyy jo vesistössä \\
\hline & 7.11 & 77 & Talvivaaran vuoto paikannettiin, vedessä runsaasti uraania \\
\hline & 8.11 & 86 & Niinistö: Hakekaa korvauksia kaivosyhtiön vahingoista \\
\hline & 9.11 & 96 & $\begin{array}{l}\text { Talvivaaran uraanipitoista vettä kulkeutunut kilometrien } \\
\text { päähän }\end{array}$ \\
\hline & 10.11 & 70 & $\begin{array}{l}\text { Sata työntekijää ja } 40 \text { kaivinkonetta yrittää tukkia } \\
\text { Talvivaaran vuotoa }\end{array}$ \\
\hline & 11.11 & 51 & Talvivaaran jätevedet saatiin padotuksi \\
\hline & 11.11 & 67 & $\begin{array}{l}\text { Luonnonsuojeluliitto hämmästelee valtiovallan } \\
\text { suhtautumista Talvivaaraan }\end{array}$ \\
\hline & 13.11 & 51 & Professori: Talvivaaran kaivosta ei kannata sulkea \\
\hline & 14.11 & 52 & Ville Niinistö: Kaikki kaivokset pannaan testeihin \\
\hline & 16.11 & 54 & $\begin{array}{l}\text { Greenpeace julkisti Talvivaarasta viikko sitten otettujen } \\
\text { näytteiden tulokset }\end{array}$ \\
\hline \multirow[t]{11}{*}{ KS } & Päivämäärä & Kommentit & Otsikko \\
\hline & 4.11 & 315 & Jätevesivuoto $5000-6000$ kuutiota tunnissa \\
\hline & 8.11 & 149 & Altaat eivät riittäneet - Talvivaara juoksuttaa nyt vettä läpi \\
\hline & 9.11 & 138 & Armeijan helikopteri apuun vuotoa tukkimaan \\
\hline & 9.11 & 169 & Ely-keskus: Talvivaara ei saa käynnistää metallitehdasta \\
\hline & 10.11 & 160 & Vuoto jatkuu - jätevesilohko kohta tyhjä \\
\hline & 15.11 & 167 & Perä kainuulaisille: “Olemme erittäin pahoillamme” \\
\hline & 25.1 & 150 & Talvivaara: vesipäästöt seitsenkertaisiksi \\
\hline & 12.2 & 185 & Lupa tuli - Talvivaara aloittaa vesien juoksutuksen \\
\hline & 8.4 & 186 & $\begin{array}{l}\text { Kipsisakka-allas vuotaa taas - juoksutuksia etelään lisätään } \\
\text { voimakkaasti }\end{array}$ \\
\hline & 29.4 & 184 & $\begin{array}{l}\text { Majavanpato sai kalkkivedet tulvimaan: Talvivaaran } \\
\text { eteläpuolisia vesiä ei pesu- tai uimavedeksi }\end{array}$ \\
\hline \multirow[t]{11}{*}{ SL } & Päivämäärä & Kommentit & Otsikko \\
\hline & 11.1 & 102 & Pappi naulaa avin oveen kaivosten ympäristöteesit \\
\hline & 4.2 & 83 & $\begin{array}{l}\text { Matti Korhonen kirjoitti ministerille: “Se oli kenttäoikeuden } \\
\text { istunto" }\end{array}$ \\
\hline & 6.2 & 126 & $\begin{array}{l}\text { Antti Lankinen kirjoitti ministerille: "Talvivaarassa } \\
\text { nerokkaita vain rahoitusratkaisut" }\end{array}$ \\
\hline & 12.2 & 123 & $\begin{array}{l}\text { Jätevesien juoksutus alkaa välittömästi - malminlouhinta } \\
\text { jatkuu heinäkuussa }\end{array}$ \\
\hline & 19.2 & 78 & Stop Talvivaara pyysi virka-apua poliisilta \\
\hline & 28.2 & 93 & Arkkipiispa Leo: Keskustelu vaahtoaa yli \\
\hline & 6.3 & 82 & Talvivaara juoksuttaa jo \\
\hline & 8.4 & 85 & Talvivaaran kipsisakka-allas vuotanee tyhjäksi \\
\hline & 8.5 & 80 & $\begin{array}{l}\text { ELY-keskus: Kipsisakkavuodon vaikutukset eivät näy } \\
\text { Jormasjärvessä ja Laakajärvessä }\end{array}$ \\
\hline & 20.5 & 86 & $\begin{array}{l}\text { Tommi Heikkinen erosi perussuomalaisten ryhmästä } \\
\text { Talvivaara-kritiikin takia }\end{array}$ \\
\hline
\end{tabular}

